\title{
Batı Muhayyilesindeki Doğu ve İstanbul'da Bir Gezgin: Adelaide Müller
}

\section{Muhittin DOĞAN1}

APA: Doğan, M. (2018). Batı Muhayyilesindeki Doğu ve İstanbul'da Bir Gezgin: Adelaide Müller. RumeliDE Dil ve Edebiyat Araştırmaları Dergisi, (12), 209-231. DOI: 10.2900o/rumelide.472766

\section{$\ddot{O} \mathbf{z}$}

\begin{abstract}
Batı dünyası yanı başlarında bulunan İslam dünyasına hep büyük ilgi gösterir. Tarihi süreç içerisinde bu dünyaya olan ilgi azalmadan devam eder. Doğu bazen korkulası bir yerdir onlar için, bazen de çok şey öğrenecekleri farklı dünya. Osmanlının gücünü kaybetmesiyle de işgal edilip yönetilecek yerler haline gelir İslam dünyasının geniş toprakları. Bu dünyayı daha iyi tanıyabilmek için Avrupa'dan ciddi sayıda seyyah, yollara çıkar. Kalemleri aracılığıyla Doğunun yaşamını, coğrafyasını, insanlarını tanıtmaya çalışır, kendi ülkelerindeki okurlara. Özellikle 19.yy'da seyahat imkânlarının gelişmesine paralel olarak seyyahların sayısında da önemli artışlar görürüz. Batılı gezginlerin en fazla ziyaret ettiği şehir ise hep İstanbul olur. Osmanlı Devletinin Sultan II. Abdülhamid yönetiminde artık son yllarını yaşadığı bir dönemde, İngiliz Büyükelçiliği’nde memurluk yapan oğlunu ziyaret için bu topraklara gelen Frederich Max Müller ve eşi Geogiana Adelaide Müller, üç ay gibi bir süre burada kalır. Bu zaman içerisinde, İstanbul'un her yerini rahatlıkla gezebilen aile, İstanbul'da geçirdikleri günleri, on altı mektup kaleme alarak Avrupa Kamuoyuna sunar ve Şarkın yorgun Sultan'ının ülkesinden mutlumemnun ayrılır. Bu çalışmada, öncelikli olarak asırlar içerisinde seyyahlar sayesinde oluşturulan Doğu imajı üzerinde durulacak sonra da Adelaide Müller’in eserinden yola çıkılarak Osmanlı başkenti ve kadınının Batı kamuoyuna nasıl tanıtıldı̆̆ı aydınlatılmaya çalışılacaktır.
\end{abstract}

Anahtar kelimeler: Osmanlı, seyahat, İstanbul, Osmanlı kadını, Şark.

\section{The Eastern World in European Thought and A Traveller in Constantinople: Mrs. Müller}

\begin{abstract}
The Western World always shows their great interest to The Islamic World that is located on the side of Europe. The interest continues increasingly through the historic process. The Eastern World is sometimes a place to be feared for Europeans, and sometimes is a different world for them to learn a lot. The vast land of the Islamic World was to become a place to occupy and manage for European after Ottoman State lost its power. A lot of itinerant who were European set off to know more that world. They try to introduce Eastern's life, geography and people to readers in their countries by using their pencils. We can see a substantial increase in the number of the voyagers in parallel with development of the travel opportunities.Istanbul has always been the most visited city by western travelers. Frederich Max Müller and his wife, Geogiana Adelaide Müller, went to Istanbul to visit their son, who works in British Embassy, and stayed there around three months last years of the Ottomans under II. Abdulhamid. Meanwhile, they could easily travel every part of the city and composed sixteen letters which are about spend their times in Istanbul and brought to the European Public. They departed happily from the tired Sultan's country of the East. Firstly, this article dwells on the
\end{abstract}

1 Dr. Öğr. Üyesi, Afyon Kocatepe Üniversitesi, Fen Edebiyat Fakültesi, Türk Dili ve Edebiyatı Bölümü, dogan.muhittin@hotmail.com, ORCID ID: 00oo-0002-3525-5981 [Makale kayıt tarihi: 17.8.2018-kabul tarihi: 6.10.2018] 
east image which was created in time by travelers and try to clarify the image what is. After that, it lay stresses on how to introduce the Ottoman capital and woman to the western public based on the work of Mrs. Müller.

Key words: Ottoman, travel, Constantinople, Ottoman woman, East.

\section{Batı Muhayyilesindeki Doğu}

\section{1 İslamî Doğunun Doğuşu}

Bazen Ortadoğu, bazen Yakın Doğu, bazen ise Akdenizli Doğu (Hentsch 2008:15) diye adlandırılan coğrafî bölgeden yükselen, Akdeniz’in politik ve dinsel coğrafyasını kalıcı bir şekilde değiştirecek olan yeni dinin mesajları, çok kısa bir sürede, Arabistan çöllerinden Çin'e kadar dayanır. İslam’ın bu şekilde yayılmasına kadar karşısında güçlü bir rakip görmeyen Avrupa Hıristiyanlığı, bu dinin sıradan, kısa soluklu bir dalga olmadığını anlayarak ona karşı bir savunma refleksi geliştirmekte gecikmez. Çünkü İslam'ın ileriye sürdüğü; kendisinden önce gelen bütün dinlerin tamamlayıcısı ve onun müjdecisi olan peygamberin de son peygamber olduğu gibi düşünceleri, kabul etmeleri imkânsızdı (Hourani 1993:8). Hemen atağa geçerek, yayılmaya başlayan bu dinin kutsallarını itibarsızlaştırma yollarına başvurmayı seçmeleri onlar için kaçınılmaz olur.

Böylece son peygamberin bir yalancı, onun kitabının da yalanlarla örülü, uydurmaca, kutsallıktan uzak bir hezeyanlar yığını olduğu ana fikri etrafında, yüzyıllarca sürecek bir karalama kampanyasının temelleri de oluşturulmuş olur. Karalama kampanyaları, Batı dünyasında dalga dalga yayılan nefretleri besleyecek; oluşan nefretlerin doğal sonucu olarak da -önceleri gizli yeryüzü cennetine duyulan arzunun eşlik ettiği kutsal toprakları kurtarma hayali somutlaşarak- Haçlı saldırıları gibi yıkımları büyük olan savaşlar ortaya çıkacaktı.

Tarih boyunca beyaz ve siyah gibi farklı olan iki büyük dünyanın birbirleriyle ilk tanışmaları da -yıkıcı boyutlarıyla insanlığın hafızalarından hiç silinmeyen- hep savaş meydanlarıdır. Bu kanlı buluşmalar, Batının bugün bile zihninden atamadığı, zaman içerisinde modern Avrupa'nın “ötekisi” olan Doğu'nun temel imgelerinin oluşmasının zeminlerini hazırlar.

Askerî-siyasî başarılarıyla, Batı içindeki kutsal toprakları kapsaması, onların en yakınında olması, Roma'ya üstün gelmesi ve 1571 İnebahtı savaşına kadar sürekli bir tehdit kılıcının Avrupa üzerinde sallanmasıyla kışkırtıcı bir dindir İslam Batı için (Said 2012:84). Savaşta ve barışta birbirlerinden artık hiç kurtulamayacak olan bu sorunlu yan yanalık -zeytinyağı ile sirke kadar birbirini tamamlayan, bir o kadar da birbirinden farkh: Karışım çok lezzetli olabilir ama bölünme çizgisi hiç durmamacasına yeniden, yeniden ortaya çlkar (Hentsch 2008:23)- kendilerini tüketen bitmez tükenmez bir hesaplaşmaya girmiş gibi asırlar boyu sürüp gider.

İslam'ın tarihsel süreç içerisinde Batı'ya doğru fetihleri arttıkça, nefret ve korkuların dereceleri zaman içinde yükselerek, Batı muhayyilesindeki yerini sağlamlaştırır. Hiç iyi tarafı olmayan Doğuluların bu dini; bütün yönleriyle kötü, şeytanla hep işbirliği içinde, Hıristiyanlığı tamamen yok etmek üzerine kurulmuş, hemen başı ezilmesi gereken bir kötülükler yumağıdır artık. Batı'nın bu tür korkularına ek olarak 'bir elinde Kuran, bir elinde kulç̧'la ufuklarında beliren bela; 1453 'te İstanbul'un fethedilmesiyle ve bu süreçte yaşananların abartılı bir şekilde Batı'ya anlatılmasıyla asırlarca etkisi silinemeyen bir karabasana dönüşür (Mansel1995:1). Bunun sonucu olarak da on dokuzuncu yüzylla kadar devam edecek, bütün kötülükleri üzerinde toplamış bir Osmanlı ve İslam imajı, Batı muhayyilesini meşgul eder. 
Doğuştan suçlu olan bu öteki, radikal farklılıkları sebebiyle Batılı öznenin istikrarlı dünyası için hep bir tehdit olarak kalır (Yeğenoğlu 2003:15).

Zaman içerisinde bazen bir barbar, bazen zarif, bazen şiddetlerle dolu bir tehditkâr, bazen sihirlerle gizemlerle dolu kaçıp sı̆̆ınılacak öteki bir diyar; bazen de Batı́nın kendi güzelliklerinin farkına varmasında dünyanın diğer bütün parçalarından daha fazla katkıları olan ayna görevini üstlenmiş çirkindir Doğu. ${ }^{2}$ Bu çirkinliklerle dolu yerler durağandır, oralarda hareket ve değişimi görebilmek de pek olası değildir. Duygusal dünyalarının içerisinde öylesine kaybolmuşlardır ki, mantıksallığın onların bünyelerine uyması beklenemez. Batı, Doğuyu tanımlarken onu kendisinin tam karşısına yerleştirir, bütün güzel özelliklerin -bilim, adalet, demokrasi, özgürlük, bozulmamış din- kendilerinde; karşıtı olan kötülüklerin ise Doğulularda olduğuna inanırlar. Hatta karşlarında öyle köhneleşmiş bir Şark görmeye başlarlar ki, zihinlerinde bir "madun” olarak düşünülen Şark konuşamaz, kendisini ifade edemez, onun yerine konuşmaya ve onu temsil etmeye yine bir Batılı mecbur kalır.

Doğu, hikâyelerde, şiirlerde, tablolarda, seyahatnamelerde hep büyülü egzotik güzellikleri olan, kavranılması zor, gizemli yerler olarak gösterilirs; ama bu güzellikler ülkesinde hoş, şehvetli Doğulu kadınların ruhundan anlamayan, kaba saba, çirkin krallar, yöneticiler ve zengin erkekler vardır. Bu insanlar, haremlerindeki o zarif, kaderlerine razı olmuş, edilgen kadınlara insancıl davranmayarak, onların bedenlerini ticari bir meta olarak kullanır. ${ }^{4}$ Bu zorbaların elinden sadece kadınlar değil; zulmettikleri halk da kurtarılmalıdır. Hiç zaman kaybetmeden Avrupa'nın romantik kahramanları, o yerlere, halkların ve kadınların iyiliği için yerleşmeli, gerçek medeniyetle onları tanıştırmalıdır. Böylece Batı düşüncesi, yayılmacı emellerini meşrulaştırıcı bir zemin de yaratmış olur kendisi için.

\subsection{Tedirginlik-Korku-Merak Dönemi}

14. 15. ve 16.yüzyllarda Batının karşısında İslami Doğu, yeni bir görünüş kazanır. Orta Asya'dan gelen, kitlesel olarak ilk karşılaşmaları I. Haçlı Seferiyle gerçekleşen, bütün "erdemsizlik, kötülük, barbarlkk" gibi olumsuz kavramları üzerinde toplayan ve savaş alanlarındaki başarılarıyla dikkatleri üzerlerine çeken Türk5, Osmanlı adıyla Avrupa ufuklarında kendisini göstermeye başlar. Bir anda beliren, Hıristiyan dünyasının önemli yerlerine göz diken ve kendisini İslam’ın temsilcisi olarak gören bu zinde gücün, korkulması ve dikkat edilmesi gereken bir yabancı olduğunun anlaşılması fazla uzun sürmez; fakat Avrupa'nın o dönemlerde içinde bulunduğu çok yönlü açmazlar, karşllarındaki tehditkâr güce karşı önlemler alabilmelerini engeller. Şehirlerin kraliçesi kabul edilen İstanbul, kanlı ve acımasız bir

Doğuyla Batının tarihsel serüvenini S. Duman: “'Uzunca bir dönem seyahat edilesi bir dünyanın hâkimi olan Doğu, her anlamda güneşin memleketi olmuştu. Aydınlık, sıcaklık ve bereketlilik kuşatmış var oluşlarını. Batı’nın zamanı gelmiş sonra. Sahnede başroller artık Batının eline geçmiş. Doğu, kendisine izin verildiği kadar var olabilmiş ışıkların altında. Tüm alkışlar calınmıs Batıca. Doğu'da başlayan tüm alkışlar bir nostalji semsiyesinin altında ve egzotik zevklerin harmanında bir fantezinin değerine indirgenmiş. Batı ilerleyişini hiç aksatmadan sürdürdükçe sadece kendi tarihini değiştirip yazmamış, dünyanın da tarihini değiştirip yeniden yazmış. Artık tüm ulvi başlangıçlar Batı'dan kimlikliymiş, $\mathrm{O}$ çalmıs, o oynamıș." Seklinde dile getirir. (bkz. Seyfeddin Duman, "Seyahati Tercüme-i Hakikat Olarak Algzlamak Yahut Tanzimat ve Servet-i Fünun Edebiyatında Seyahat”, Hece - Gezi Özel Sayısı, S. 174-175-176, 2011, s. 174)

3 "Doğu kavranamaz. O her yerde ve hiçbir yerde. Kitaplarda, tuvaller üzerinde, ekranlarda, sokakta, çok yakın ve hiç kuşkusuz çok uzak, başka yerlerde. Bütün donmuş kalıpların buluşma noktası, bütün egzotizmlerin eşanlamlısı, bütün çeliş̧kilerin ve bütün aşırılıkların kışkırtıcısı, daha bilge ve daha çılgın, daha çileci ve daha şehvetli. daha zalim ve daha incelikli... Çok eski, tarihin ilk şafağı ve karanlığı... Uçsuz bucaksız. Hayal gücümüzün uçsuz bucaksız kırk ambarı” (bkz. Thierry Hentsch, Hayali Doğu, Batı’nın Akdenizli Doğu'ya Politik Bakışı, çev: Aysel Bora, Metis, 2008, s. 13.

4 Avrupalı ve Doğulu erkeğin gözünde Doğu kadınının yeri hakkında daha fazla bilgi için Rana Kabbani'nin Avrupa'nın Doğu İmajı adlı eserine bakılabilir. (bkz. Rana Kabbani, Avrupa’nın Doğu İmajı, Bağlam, 1993, s. 85-104.)

Avrupa'da özellikle de Alman edebiyatında Türk imajının tarihsel gelişimini Onur Bilge Kula ayrıntılı olarak eserlerinde ele alır.( bkz. Onur Bilge Kula, Batı Edebiyatında Oryantalizm I-II, İş Bankası, 2011.) 
kuşatma sonucu, ufuklarında gördükleri yeni gücün eline geçerken Avrupa bu büyük olayı, çaresizlik içerisinde seyretmekten başka bir şey yapamaz.

Avrupa kamuoyunda İstanbul'un fethi ve sonrası yaşananlar derin ve onarılması zor yaralar oluşturur. Çünkü o sürece tanıklık edenlerin anlattıkları barbarlıklar, insan aklının ve vicdanının kabul edebileceği türden şeyler değildir: "Bir tarafta, kanlı derelerin içinden Haliç’e doğru akıp giden gövdesiz kelleler, bir tarafta kulhçtan geçirilen erkekler, başka bir tarafta ise saçlarından birbirlerine bağlanmış genç kadınlar, çirkin sonların beklemekte..."dirler. ${ }^{6}$ İstanbul'un alınmasından sonraki süreçte, artık Türk kelimesi, hiçbir olumlu sıfatları bünyesinde barındırmayan ürkütücü bir fenomene dönüşür.

Tedirginliklerle başlayan ilk tanışmanın ardından, Osmanlının zirvesi kabul edilen Kanuni döneminde, Batı, yanı başlarındaki düşmanlarını daha yakından tanıma gayretlerine girişir. Tiyatro, opera gibi sahne oyunlarında kullanılan Türk temaları; intikam, entrika ve şiddet kelimelerini içinde bolca bulundurmaya başlar (Parla 2012:36). Bunun yanında Türk saraylarındaki sultanların, paşaların ihtişamları, kıskançlıkları, yeniçerilerin gücü, bu büyük imparatorluğun egzotik ve barbar atmosferi geniş yer bularak (Eravcı 2010:50-51), Avrupa kamuoyunun hafizalarına kazınır.

Viyana bozgunu(1683) sonrasında, Türk imajında tam bir kırılma yaşanacaktır, artık Avrupa, karşısında yenilmez bir ülkenin olmadığı görüşünü benimseyerek, bu ülkenin zayıf noktalarını gerçekçi bir gözle inceleme işine koyulur. Daha önceleri, üzerlerine akınlar yapan barbarların ülkesi olarak kabul ettikleri güçlü dünyayı, korkulardan azade derin tahlillerle anlamaya çalışırlarken, oraların eski canlılıklarından uzak, durağan, dışlarındaki dünyalardan, gelişmelerden habersiz, kurumları da yozlaşmış yerler olduğunu keşfetmekte fazla geç kalmazlar.

Diğer bir yandan, korkuların atlatılmasıyla Fransa'da bir egzotik tutkuya dönüşen Doğu hayranlığı, Antoine Galland'ın Bin Bir Gece Masalları'nın çevirisi ile kendisine konforlu ve geniş bir alan bulur. Merak ve elde edilen bazı imtiyazlar sayesinde Doğu’ya seyyahların akını daha da artar.

Bu dönemlerde, Lady Mary Wortley Montagu'nun yaptığı çalışmalar sayesinde Osmanlı kadını ve haremi, erkeklerin oluşturduğu hayali-soyut bir dünyadan styrllarak reel-somut bir çehreye bürünür. Avrupa'da pozitif düşünce ve eğitimin zamanla önem kazanmasıyla Türklerle ilgili olumsuz görüşlerin azalması beklense de yüzyıllarca işlenilen önyargıların gölgesi altında, bunun gerçekleşebilmesi pek mümkün olamaz (Şahin 2007:48).

\section{3. Özgüvenle Yaklaşılan Doğu ve Olumsuz İmajlar Dönemi}

Aydınlanma dönemine giren Avrupa'da, geçmişi başarılarla dolu ama içinde bulunduğu süreçte durağanlığa geçmiş Osmanlı Devleti’nin gelişmelere ayak uydurmasının imkânsızlı̆̆ konuşulmaya başlanır. Dinlerinden ve yapısal özelliklerinden kaynaklı çağdaşlaşmaları imkânsız gibi görünen İslam dünyası (Osmanlı), gelişmiş, aydınlanmış, çağdaş Avrupa'nın karşısına; bilgisizlik, fanatiklik, gericilik gibi bağnaz imajları yüklenmiş olarak yerleştirilir. Osmanlı'nın zayıllamasına paralel olarak elçilikler vasıtasıyla -özellikle Venedik elçilikleri- Avrupa’ya yayılan olumsuz algıların derecesi de artar. Hatta yeryüzünün en büyük zulüm hanesi gibi adlandırmalar artık sıradanlaşır Osmanlı için. Montesquieu'nun fikri zeminini oluşturduğu ve Osmanlı'nın üzerinde şekillenen Doğu Despotizmi kavramının etkisiyle pek çok yazar, seyyah, Doğu'da bu kavramın belgelerini, izlerini bulabilmek için

İstanbul'un fethi sırasında yaşanılanların Hıristiyan Avrupa dünyasına nasıl yansıdı̆̆ ile ilgili ayrıntılı bilgi için Andrew
Wheatcroft The Ottomans adlı kitabının "The World's Last Day" bölümüne bakılabilir. (bkz. Andrew Wheatcroft, The Wheatcroft The Ottomans adli kitabinin "The World's
Ottomans, Dissolving İmages, Penguen, 1993, s. 1-22). 
yola çıkar. Bu amaçla yollara düşen Avrupalı gezginler, genelde ellerinde despotizmin kaynağı olarak iki somut veriyle ülkelerine dönerler: Bunlardan birincisi, halkları yöneten -başta sultan- zalim idareciler; ikincisi ise onların ilerlemesinin önündeki en büyük engel olan dinleridir.

Avrupa, bilimin kendilerine verdiği güç ve ışıkla geri kalmış bu bölgelere müdahale etmeli ve onları köhnelikten kurtarmalıdır. Bunun da aydınlanmış Avrupa'nın en doğal hakkı olduğuna inanılır. Zaman içerisinde, Avrupa İslam'ı ve onun mensuplarını daha iyi tanıma faaliyetlerini hızlandırır. Cambridge(1632) ve Oxford(1636) kurduğu bölümlerle Müslüman ülkelerin dillerini ve kültürlerini öğretmede öncülük eder. Yapılan çalışmalar, başlangıçta politik bir amaçtan ziyade misyonerlik ve ticari tarafı ağır basan girişimlerdir. 17. asır boyunca Avrupa ülkelerinin misyonerlik faaliyetleri ile ticari faaliyetleri Hindistan ve Ortadoğu gibi iki büyük İslam coğrafyasında paralel bir şekilde devam eder. Fakat bu süreçte Doğu hakkında elde edilen veriler, bilgiler, dokümanlar, Batılı güçlerin siyasi iştahlarını celp etmede gecikmez.

Zenginlikleri tarihsel derinliklerden de beslenen Doğu'da, geçici bir misafir olmak yerine; oraların kalıcı sahipleri olmanın yollarını araştırmak kutsal görevleri olur, emperyalist iştahları sınırlar ötesine çoktan taşmış olan Batı dünyasının. Amaçlarına ulaşmada en büyük silahlarının kendilerinden olmayan öteki hakkında elde edilecek bilgi olduğunu anlamalarıyla da bir bilgi toplama yarışına girişilir. Bu -amacı bilgilenmekten ziyade- bilginin verdiği güçle kendinden olmayanları hükmetmek ve onları sömürmek olan bir yarıştır (Hüssain 1984:8-10). Öncülüğünü de Silvestre de Sacy Paris’te(1795) Ecole des Languees Orientales’i açarak başlatır. Böylece Batı hegemonyasının gölgesinde, üzerinde her türlü ameliyatların yapılabileceği, sadece gözlemsel gerçekliğin değil; aynı zamanda arzuların, çıkarların ve ön yargıların da katkısıyla çok boyutlu bir Şark yaratılır.

On sekizinci yüzyıl Batı'nın Doğu karşısındaki üstünlüğünün ve farklılığının belirgin bir şekilde ortaya çlktığ 1 bir dönemdir. 'Kendisini tehdit altında hissetmeyen, kimseyi de tehdit etmek istemeyen birinin güven dolu sükûneti’ ve özgüveniyle Avrupa (Hentsch 2007:170), Doğuyu inceleme alanına alır. Çünkü tarihsel düşmanı ve rakibi; despotizmin, fanatizmin, bilim düşmanlığının, geri kalmışlığın o iflah olmaz sarmalı içerisine çırpındıkça batmaktadır.

Bu dönemde, Batı'nın Doğuyu ele alış şekli ne sonraki ne de önceki dönemlerdeki gibi olacaktır, daha yansız daha nesnel bir şekilde Doğu anlaşılmaya çalışılır7. Diğer birçok zaman diliminde olduğunun aksine, Batı kendinden kaçmak, egzotizmde rahatlamak için Doğu'da değildir; ötekini anlayıp, anlamlandırmaya çalışırken kendini daha farklı açılardan görmek, daha iyi tanımak için oralardadır8. E. Said, bu yüzyılda, Doğu-Batı ilişkisinde göz ardı edilemeyecek iki temel özelliğe dikkat çeker:

“Onlardan birincisi, gelişen yeni bilimlerin, sömürgelerle kurulan ilişkilerin, romancıların, ozanların, yetenekli gezginlerin katkıları sayesinde giderek genişleyen düzenli bilgi akışı olması; diğeri ise bu ilişkinin Şarkı, Şarklıyı ve Şarklının dünyasını yaratan güçlü taraf ile zayıf taraf arasında oluşan bir ilişki olmasıdır.” (Said 1995:49)

\footnotetext{
7 18. yüzyılda iyimserliğin Batılılar için hakiki bir din olduğundan yola çıkarak M. Rodinson, Doğuya yaklaşımın da biraz bu nedenden Batı tarafından kardeşçe olduğunu belirtir, kusurları fazlaca görülmeyen bir kardeş. (bkz. Maxsime Rodinson, İslam'n Mirası, Pınar, 2003, s. 64.)

$8 \quad$ Biz kimiz? Doğu’nun ön yüzü mü? Ötekinin ötesi mi? Pozitif kutup mu, doğrulanmışlk mı? Ama kimi zaman da madalyonun öteki yüzü; pozitifin negatifi. Böylece eski simgeler su yüzüne çıkıyor: Bir an için Doğu ışıktır, evrensel ruhtur, iç dünyamızın sihirli mıknatısıdır, beceriksiz modernliğimize karşı takınılan bir mesafeliktir. Ama en küçük bir olayda, sıçrayan ilk kanda, ışık titreşir, söner: Doğu bizim korkumuzun balçı̆̆ı içine gömülür; unutulmuşluğa geri çekilir, sonra düş olarak geri döner. Yol dönemecindeki sahte parıltı. Süs. Serap. (bkz. Thierrry Hentsch, Hayali Doğu, Batinnn Akdenizli Doğu'ya Politik Bakışı, çev: Aysel Bora, Metis, 2008, s. 13.)
} 
Fakat yüzyılın sonuna doğru, iyi niyetli yaklaşımlar yerini sahiplenme arzularına bırakır. Yaratılan yeni Şark'ın ameliyat masasına yatırılma zamanı da gelir ve büyük ameliyatın başlangıcı, Napolyon'un sadece askerlerle değil; geniş bir bilim adamı ordusunu da arkasına alarak yaptığı Mısır’ın fethi ile olur. " $B u$ bilimin silahla, kalemin kılıçla ittifakın gösteren” (Bulut 2010:90) Batı’nın daha güçlü ve bilimsel bir disiplinle Şarkta yaşamasını sağlayan öncekilerden farklı bir sefer olur. Napolyon’un girişimi, daha sonraki Garplı fatihlerin yoluna ışık tutacak 23 bölümden oluşan bir külliyatı arkasında bırakır. Mısır'ın sadece askerlerle değil bilim adamlarıyla da fethedilmesi, Avrupa'nın sömürgeci tarihinde yaptıklarını meşru göstermek gibi yeni bir sayfayı da açacaktır. Onlar Mısır’ı işgal etmek için gelmediklerini, tam aksine şanlı bir geçmişi olan medeniyetlerin beşiğini, eski muhteşem tarihine geri kavuşturmayl; hatta daha da ileriye götürmeyi amaçladıklarını belirtirler. Böylece onlar hiçbir zaman bireysel ve edilgen olmayan Batı'nın temsilcisi yüce soylu kurtarıcılardır, artık.

\title{
1.4. Bilginin Sağladığı Güçle Yeniden Dizayn Edilen Coğrafyalar
}

Gücünün zirvesine ulaşan 19.yüzyll Avrupası için Doğu, hala bir düşmandır; "ama artık peşinen yenilmiş bir düşmandır. Er geç Avrupahlaşacaktır. Zaafi yüzünden acınacak haldedir. Yırtıcılĭ̆ bile kimseyi kızdırmıyor artık. Baş eğen düşmana savaşı sen kazandın demek kolay ve hoş bir şey. Barbarlk bir mizaç meselesidir deyip geçiliyor, bir tehlike olmadiktan sonra bol bol övebilirsiniz."(Rodinson 2003:76). Fakat bundan sonra artık zararsız bir düşmandır.

Batılı gözlerin yoğunlaştı Osmanlı coğrafyası, olumsuzluklarıyla dikkatleri üzerine daha fazla çekmeye başlar. Uzaktan güzel görünen şehirlerinin -özellikle de Batının hayallerini asırlar boyu süsleyen İstanbul'un- yakından bakıldığında bütün sihri, büyüsü, güzelliği kaybolmakta; dar, pis sokaklar, iğrenç binalar ve caddeler, başıboş köpekler; köşelerde, kenarlarda tembel, dürüstlüklerini kaybetmiş uyuşuk, iş bilmeyen insanlar, bu payitahtın acınası realitesi olarak karşımıza çıkar. İmparatorluğun güç kaybına paralel olarak her alanda ortaya çıkan yozlaşma, Avrupalı ziyaretçilerin gözlerinden kaçmaz:

\begin{abstract}
"Osmanlı ülkesinde adalet hep güçlülerin yanındadır, rüşvet devlet dairelerinin her alanına girmiştir, ticaretleri de eksik tartı gibi hilelerle doludur. Bir zamanlar adıyla Batıya korku salan o güçlü ordunun yerini tam bir düzensizlik ve başıboşluk almıştır. Bu ülkede yaşayan insanlar da zamanın kıymetini hiç bilmeyen oldukça tembel insanlardır, bu tembellikleri yüzünden bütün büyük parasal işler Ermeni, Rum ve Yahudilerin ellerindedir, kendileri ise daha çok tarımsal faaliyetlerle uğraşırlar. Bereketli yıllarda elde ettiklerini müsrifçe harcarlar, kurak yıllarda ise açlık tehlikesiyle -birikim bile yapmadıkları için- yüz yüze kalırlar. Kahve, nargile, şerbet özellikle de tütün içimi bu toplumun önemli karakteristik özelliklerindendir. Türklerin tütüne düşkünlükleri anlatılırken dünyada bu kadar tütün içebilen başka bir milletin olamayacağı özellikle vurgulanır.”9
\end{abstract}

On dokuzuncu asır, günümüzde de hala etkilerinin devam ettiği İslami Doğu ile ilgili birçok önyargının üretildiği bir zaman dilimi olur. Müslümanların bilgi üretemeyeceği, kadınların özgür olmadığı, bu dünyanın aydınlanamayacağı, geri kalmışlığın onların tembel yapılarından kaynaklandığı, Batı standartlarında bir gelişmeye hiçbir zaman ulaşamayacakları gibi peşin hükümler ve cinsel fanteziler bunlardan bazıları ${ }^{10}$. Bütün bu olumsuzlukların kaynağının da İslamiyet olduğu genel kabul gören bir

\footnotetext{
9 Türklerin Batılı gözündeki kişisel özellikleriyle ilgili daha detaylı bilgi için Gürsoy, Şahin’in çalışmalarına bakılabilir. (bkz. Gürsoy Şahin, İngiliz Seyahatnamelerinde Osmanlı Toplumu ve Türk İmajı, Gökkubbe, 2007, s. 323-336.)

Bu dönem Batılı romantik tabloların ve siirlerin "bir renk, bir debdebe, barbarca bir vahset cümbüsü, haremler, saraylar, kesilen kelleler, çuval içinde denize atılan kadınlar, filikalar, hilalli sancaklarla süslü kadırgalar, lacivert kubbelerin yuvarlaklığı, beyaz minareler, odalıklar, harem ağaları, vezirler, hurma ağaçlarının altında çeşmeler.” konularını oluşturur. Oluşturulan bu renkli Doğu imajı da keyfi yerinde Batı burjuvalarının derin içgüdülerini, bulanık şehvaniyetlerini, şuuraltı mazoşizm ve sadizmlerini tatmin eder. (bkz. Maxime Rodinson, İslamın Mirası, Pınar, 2003, s. 75-76.)
} 
kanıdır. Bu olumsuzluklarla dolu dünya batının elde ettiği geniş bilginin ışığı altında yeniden inşa edilmelidir (Kalın 2016:313)

Zikredilen fikirlerin uzağında bir de Doğu'yu mistisizmin, egzotizmin, şiirselliğin beşiği olarak gören ve yücelten entelektüeller vardır. Ama başta Nerval, Flaubert ve Isabele Eberhardt olmak üzere birçok entelektüel, Doğu’da hayallerinde oluşturdukları Şarkı bulamayarak yok edilen ‘Öteki’ye özlem’ (Behdad 2007:32)ve düş kırıklıklarıyla dönüyorlardı anavatanlarına:

\begin{abstract}
"Avrupalılar birbirine zıt uçlara savrulup duruyorlardı. Doğu. Ya yeterince 'oryantal' değildi, ya da aşırı 'oryantal' idi. Yolculuk, ya hayal kırıklı̆̆ına uğratıyordu, çünkü her şey Batı etkisiyle dönüşmüş oluyordu, ya da sanki çok olumsuz görünebilmek için, acınacak kadar Batının etkisinden sıyrılmış oluyordu. Aynı gezgin, bu aşırı uçlardaki duyguların hepsini birden yaşayabilirdi. Napolyon Mısır'ın daha da egzotik olmasını isterdi ve onu Batı tipi, kaba bir uygarlığa (hem de ne çatal bıçağı ne de soyluları olan) bir ülkeye dönüştüren, o yetersiz egzotizmi kü̧̈ümsemekteydi.” (Kabbani 1986:164).
\end{abstract}

On dokuzuncu yüzyılda Batı'nın Doğu'ya yaklaşımını, “Modernliğin Doğusu” bölümünün girişinde Thierry Hentsch: "Modernliğ in Doğusu modern Doğu değildir. Bu, 19. yüzyıldan başlayarak, Avrupa modernliğinin araşttrdığı, didik didik ettiği ve yuttuğu bir Doğu'dur. Gerçek Doğu, düşlerdeki Doğu. Güçler dengesinin kurbanı ve hayal ürünü. Aynı açgözlü bakış altında iç içe geçmiş çok yüzlü Doğu: Bathl topun tüfeğin, sermayenin ve fantazmalarn kurbanı" (Hentsch 2007:172) şeklinde özetler. Bu cümlelerden yola çıkarak Batı muhayyilesinin Doğuyla ilgili oluşturulan karmakarışık, bölük pörçük, düzenli düzensiz, hayali, birbirleriyle çelişen birçok bilgi yumağı yükünü, sırtına alıp 20. yüzyıla girmiş olduğu yargısına ulaşabiliriz.

Batılı düşünceyi, en fazla meşgul eden konulardan birisi de Boğazın hasta adamı -ölesiye hasta adamıOsmanlı İmparatorluğu'nun durumudur. Dört bir tarafında isyanların başladığı bu büyük enkazı, çeşitli güç dengeleri içerisinde zararsız bir şekilde sonuçlandırmak oldukça zordur. Çünkü bu güçsüz imparatorluğun elindeki klymetli ve kutsal topraklar, bütün emperyalist güçlerin ilgi alanına girmektedir. Özellikle Balkanlar gibi güzide topraklar ve oraların medeni halkları mutlaka bu barbarlardan kurtarılmalıdır (Kula 2012:xxı). Bu arada, içerisinde çıkan isyanlar karşısında Osmanlı'nın yaptığı müdahaleler, tek taraflı ve yanlı olarak ele alınarak, zaten kötü olan Osmanlı imajı daha da karartılır, Batı kamuoyunda. Buna karşılık azınlıkların isyanlar sırasında Müslüman Osmanlı tebaasına yaptıkları insanlık dışı katliamlar, gözlerden uzak tutulur(Wheatcroft 1995:234). Bunca problemin çözülmesi için sanki büyük bir savaşa ihtiyaç vardır ve 20. asrın başında da bazı problemleri çözerken, daha büyüklerine zemin hazırlayan bir savaş kendini gösterir.

\title{
1.5. Yeni Çağ ve Derinleşen Meseleler
}

Çok derin yıkımları ve sonuçları olan iki büyük savaşı içerisinde taşıyan 20. asır, Şarkiyatçılık açısından yeni bir dönemin başladığını haber verir bizlere. Artık Batının karşısında kaderlerine razı olmuş, her türlü ameliyata hazır pasif bir nesne yerine; talepleri olan, kendi adına konuşma cesaretini eline almaya çalışan, onların sömürü düzenlerine en büyük tehdit olarak karşılarına dikilen ve yazılan bütün senaryolarda özne olmaya çalışan bir İslam dünyası vardır.

İki büyük savaşın Batı'da meydana getirdiği yıkımlar ve Şark’ta ortaya çıkan yeni tarz uyanışlar, Batı dünyasının özgüvenlerinde bir sarsılmaya yol açar. Sanki Avrupa-merkezciliği tarihe karışıyordur (Rodinson 2003:89). Ülkeler üzerindeki sömürgeci isteklerinden asla vazgeçmeden, eski yöntemlerinin işe yaramayacağını görerek, yeni yaklaşım yolları aramaya başlayacaklardır, Şarktan vazgeçmeye niyetli olmayan sevdalıları. Özellikle II. Dünya Savaşı, Avrupa ülkeleri için büyük bir yıkımdı. Bu yıkımın doğal 
sonucu olarak Amerika'nın çekim alanına geniş şekilde giren İslam dünyası, sadece akademisyenlerin, siyasetçilerin ilgi alanlarında kalmaz. Bunun yanında Ortadoğu, yer altı ve yer üstü zenginlikleriyle büyük ticari şirketlerin de dikkatlerini yoğun şekilde üzerlerine çeken bir bölge haline gelir. İngiltere ve Fransa'dan devralınan Şark çalışmaları, sadece muğlâk filolojik bir bilgi birikimi olmaktan çıkarılır. Yeni alt başlıklar ve bilim dallarıyla zenginleştirilerek daha etkin bir saha haline getirilir.

Batılı değerlerin 20. ve 21. Asırlarda en büyük temsilcisi ve hamisi olan Amerika'nın önceki dönem sömürgecilik mirasından göreceli uzak oluşu, ABD'nin İslam dünyası üzerinde yeni bir anlayışla hâkimiyet kurma işini kolaylaştıracaktır:

\begin{abstract}
“ABD, Avrupalı sömürgeci devletlerin Asya ve Afrika topraklarındaki kirli mirasına bulaşmamıș olduğu şeklindeki - gerçekte bir yanılsamadan ibaret olan- görüntüsü nedeniyle Batı dıșı toplumlarla 'daha dostça ve sıcak' ilişkiler kurabilme başarısını göstermiştir. Kendi emperyalist sistemini, Batı dışı toplumlara da 'görece' bir konum vererek önceki sömürgeci sistemden değişik bir tarzda kurmuştur. Oryantalist bilgi üretiminde de ABD, benzer şekilde, ayırımcı bir tavır takınmamıştır. Bilgiyi 'asil' ve 'adi' diye ayırmamış, kendi üstünlüğünü devam ettirecek bilgiler 'kimden ve 'nasıl' gelirse gelsin pragmatik bir tarzda kullanabilmiştir. Sahip olduğu askeri, iktisadi ve siyasi güce bağlı olarak da, toplumlararası farklılıkları, kendi üstünlüğünü besleyen zenginlikler haline başarıyla getirebilmiştir." (Bulut 2010:146).
\end{abstract}

Amerikan popüler kültürünün yayılmasında en güçlü silahlardan sinema, yeni bir İslam dünyası imajının oluşturulmasında, üzerine düşen görevi yerine getirme gayretleri içerisine girer. Başta Araplar olmak üzere bütün Ortadoğu halkları, yeni bir imaja büründürülür. Bu yeni görünüm, özünde tarih boyunca Avrupa'da var olagelmiş düşüncelerden fazlaca da farklı değildi. Hollywood filmlerinde, sadece Hıristiyan Batı'nın değil, bütün dünyanın bolca seyredeceği Müslüman karakteri ise genelde; hiç güven olmayan, yalancı, düzenbaz, şehvet düşkünü, demokrasiden ve insan haklarından nasibini almamış, bulduğu her fırsatta Batı'ya ve onun kültürüne cihat etmeye hazır, çirkin, zalim insan tipleridir. Onların karşlarında ise; bütün iyiliklerle donatılmış, güçlü, kuvvetli ve görüntüleri de çok düzgün, İslam dünyasına demokrasi ve insan haklarını götürmek için çalışan, bütün zorlu mücadelelerin sonunda da hep galip gelen Amerikalı iyilik savaşçları olacaktır.

20. asırda kendisini daha fazla gösteren, Batı’ya doğru İslam ülkelerinden öğrenci akışı özellikle II. Dünya savaşından sonra yönünü Amerika'ya çeviriri11. Şark’tan gelen öğrenci ve hocalar, Amerikalı araştırmacılar için akademik standartları olmayan, yaptığı çalışmalara da güvenilmeyecek kişiler olarak kabul edildikleri için onlara sadece kaynağından Batı'ya Doğu’nun malzemelerini taşımaya yarayabilecek insanlar olarak bakılır ve bu şekilde faydalanılmaya çalışılır ${ }^{12}$. Şarklı akademisyenler, eğer dünyada ve ülkelerinde kabul görmek istiyorlarsa Avrupa standartlarına da uymak zorundadır. Bunun da anlamı; Batılı akademisyenlerin Doğu hakkında ileri sürdükleri bütün doğmaları, gerçeklerle ilgisi olmayan görüşleri ve ülkelerinden çok Batı’nın çıkarlarına yarayacak tezleri benimsemek zorunda olmalarıdır ki, ilim dünyasında kabul görebilsinler (Bulut 2010:144). Ĕ̆er Batı çıarlarına ters düşen veya Batı'ya kendi ülkelerinden bilgi ve kaynak taşımayı reddederek, Batı'yla ilgili derin analizlere girmeye cüret eden akademisyenler, öğrenciler karşılarına çıkarsa, onları başarısız ve itibarsız gösterebilmek için köşe başlarını tutmuş Batı'nın kalemler harekete geçmekte hiç gecikmez. Batıya ilim tahsil etmek için giden öğrencilerin önemli bir özelliği de yeterli entelektüel donanımlara sahip

11

ABD'de bu dönemlerde Ortadoğu'yla ilgili enstitülerin kurulmasının yanında; Şarkiyatçılık çalışmalarının daha güçlü bir zemine oturması için de Avrupa ülkelerinde bulunan belli başlı Oryantalistleri transfer edip, kendi üniversitelerine kazandırma yollarına da gidilir. Hamilton Alexander Roskeen Gibb, Gustave Edmund von Grunebaum ve Türkiye çalışmalarıyla öne çıkan Bernard Lewis bunların en tanınmışlarındandır.

Günümüzde bile ülkemizden Batı ülkelerine doktora çalışmalarına giden öğrencilerin tez konularına şöyle bir göz atıldığında, büyük çoğunluğunun ülkemize yeni bilgilerle dönmek yerine; oralara belgeler taşıyarak akademik kariyerlerini elde ettiklerini açı bir şekilde görebiliriz. 
olamamalarıdır. Bunun sonucu olarak karşılarına çıkan Avrupa kültürünü kendi ülkeleri yararına sentezler yapabilmeyi başaramayarak karmakarışık bir düşünce dünyasıyla ülkelerine dönerler (Kalın 2016:370).

İçinde yaşadığımız 21. asırda, beşeri ve teknik bilimlerde büyük ilerlemeler olmasına rağmen, Batı́nın Doğuyla sorunu sağlam bir zemine oturtulamayarak, Oryantalizm kitabının yazarının iyimser öngörüsünün aksine daha büyük ve karmakarışık bir problem olarak tarih sahnesindeki yerini korumaktadır. Yaklaşık yüzyıl önce hem İslam dünyasının hamisi hem de temsilcisi olan 'Hasta Adam' gider, ondan boşalan coğrafyalarda onlarca yeni ülkeler ortaya çıkar; ama bu yeni ülkeler, yapay bölünmeler yüzünden istikrarı ve huzuru yakalayamazlar. Kendi ülkelerinde mutlu olamayan birçok Müslüman, zaten dinlerinin geleneğinde var olan hicret duygusuyla daha huzurlu, refah ülkeler arayarak, büyük çoğunluğu, bir Hıristiyan topluluğu olan Batı ülkelerine yerleşmekte ( iç içe yaşadığı) ve beyaz adamdan kendi seslerini de duymasını beklemektedir (Said 2004:24). Veya Batı'nın ucuz iş gücü ihtiyacını karşılamak amacıyla ülkelerinden -yeni bir emperyalizm anlayışılla- koparılmaktadır (Young 2000:270). Böylece milyonlarca Müslüman Batı'nın merkezinde kendi küçük dünyalarını, gettolarını kurarak, izole bir yaşamın ortasında bulmaktadır kendilerini.

Batı’ya yerleşmelerine rağmen onların hep "Ötekisi" kalan ve arzuladıkları huzuru bulamayan, kendi topraklarından kopup gelen bu insanların pek çoğu, özellikle de gençler, mutsuz bir hayat sürmekte ve onlara göre hem kendilerinin hem de kopup geldikleri yerlerin huzursuzluğunun temelinde Avrupa'nın ve Amerika'nın -ülkeleri üzerindeki- emperyalist emelleri yatmaktadır. Bu görüşe Fanon'un da: “Sürekli kendisiyle konuşması ve giderek iğrençleşen narsizmi, kaçınılmaz olarak yarı deliliğe ortam hazırladı; entelektüel düşünce bir ıstırap halini ald, çünkü yaşayan, çalışan, kendini yaratan bir varlık olarak insanın gerçekliğinin yerini sözler, bir araya getirilmiş sözcükler ve anlamlarının yarattı̆̆ gerilimler aldı (Fanon 2013:305).” sözleriyle fazla uzak olmadığını gözlemleriz.

Avrupa'da ötekileştirilmiş, örselenmiş gençlik, kendilerine bir çıkış yolu aramaya çalışırken, insanlık için hiç de hoş olmayan mecralarda, kendilerini ispatlama yollarını seçmekte ve çözümü, şiddete başvurmakta arayabilmekte ve bunun sonucu olarak da artık ne Amerika ne Fransa ne Almanya ne İngiltere ne de diğer Batı ülkeleri, güvenli bir yerdir; ancak radikalleşmiş gençliğin eylem mekânları olabilmektedir. Bu eylemlerin saldıkları korkular yüzünden, milyonlarca insan evlerinden çımaya korkar hale gelebiliyor veya televizyonumuzun başında, patlayan bir sokak lambasının sesini bile terör saldırısı zannederek yerlere yatan, kaçışan Paris halkının perişan halini üzülerek seyredebiliyoruz. Yüzyıllardır devam eden Doğu-Batı sorunu, çatışması, artık uzak ücra köşelerde değil Avrupa'nın merkezinde daha da büyümüş, sorunlar yumağı olarak, muhataplarının kucağında çözülmeyi beklemektedir.

\section{Georgina Adelaide Müller ve İstanbul Mektupları (Letters from Constantinople)}

\subsection{Yazarın İstanbul'a Gelişi}

Osmanlı Devletinin Sultan II. Abdülhamid yönetiminde artık son yıllarını yaşadığı bir dönemde, İngiliz Büyükelçiliği’nde memur olan oğlunu ziyaret için bu topraklara gelen Frederich Max Müller ve eşi Georgiana Adelaide Müller, üç ay kadar kaldıkları zaman içerisinde, Max Müller’in tanınmış bir filolog ve oryantalist olması hasebiyle, ailece Sultan tarafından büyük hürmet ve ilgiye mazhar olurlar. Birçok yabancıya nasip olamayacak bu ilgi sayesinde, Müller ailesi, Topkapı Sarayı'nın ve Yıldız’n bütün bölümlerini rahatlıkla gezer, Sultanın onların rahatça dolaşabilmeleri için yanlarına görevlendirdiği 
saray yaveri sayesinde, istedikleri her yere, sorunsuzca girip çıkabilirler. Yıldız'da Sultan'ın huzuruna çıkabilmek, onunla yemek yiyebilmek, ondan ödüller alabilmek ve hatta oldukça az konuşan Osmanlı Sultanından iltifat dolu sözler duyabilmek, bu şanslı İstanbul ziyaretçileri için çok da zor olmaz.

İmparatorluğun karanlık yıllarında, yüz yüze kaldığı olumsuzluklara şahit olan aile -çoğu Avrupalı seyyahın- ziyaretçinin aksine, Osmanlı toplumuna büyük bir anlayış ve sevgiyle yaklaşan ender insanlardandır. Özellikle bütün Avrupa kamuoyunun acımasız saldırısı altında olan Sultan II. Abdülhamid'e yaklaşımları, oldukça dikkat çekicidir. Onun Osmanlı'nın modernleşmesi için yaptığı çalışmaları dile getirerek, ne kadar çalışkan, milletini de o denli düşünen, zeki, ince ruhlu bir hükümdar olduğunu özellikle belirtirler.

İstanbul'da geçirdikleri günleri, on altı mektup kaleme alarak Avrupa Kamuoyuna sunan iki yazar, Şarkın yorgun Sultanının ülkesinden mutlu ve memnun ayrılır. Max Müller tarafından yazılan dört mektupta, daha çok İslam dini, onun peygamberi, İslam ve Hıristiyanlık gibi iki büyük dinin birbirlerine yaklaşımları, Türk insanının özellikleri, sosyal yaşamları, İstanbul'un sokaklarının, evlerinin durumu ve farklı dini inanışlar gibi konular üzerinde durulur. Diğer mektuplarda, Georgiana Adelaide Müller, İstanbul manzaralarmı, Osmanl kadınını dünyaya kapalı mutsuz hallerini, saraylarm durumlarm, kutsal değerleri, kutsal günlerdeki merasimleri, Boğazın, mesire yerlerinin güzelliklerini, bu ülkeye ve insanına beslediği sevgiyi ruhunun inceliklerini de katarak ortaya koymaya, gün yüzüne çıkarmaya çalışır. Eser boyunca okuyucu, yazarın Osmanlı dünyasına sevgi dolu yaklaşımının hiç eksilmeden devam ettiğine şahit olur.

Bu yazıda, çalışmanın boyutlarını aşacağı gerçeğinden yola çıkarak Adelaide Müller’in eserini bütün yönleriyle ele alıp incelemek yerine; onun İstanbul'a bakışı ve Osmanlı kadınlarına yaklaşımı üzerinde yoğunlaşacağız

\section{2. İstanbul}

\subsubsection{Tarihi Macerasi}

İstanbul, tarih boyunca coğrafi konumunun ona sağlamış olduğu güzellikleriyle ve büyük imparatorluklara -Roma, Doğu Roma ve Osmanlı- başkentlik yapmasıyla, onun dışındaki dünyaların arzularını hep üzerine çeker (Mansel 1995:2). Üç tarafı denizlerle çevrili, Asya'yla Avrupa'nın birbirlerine kavuştuğu bir noktada kurulmuş olan şehirlerin sultanının başı, güzelliğinden dolayı belalardan hiç kurtulamaz. Onu fethetme sevdalıları, türlü zorlukları göze alarak uzak diyarlardan yollara çıkar; ama çoğu ya yollarda ya da onun aşılmaz surlarının dibinde canlarından olur. Sanki İstanbul, aşığının canına kasteden ve ona hiç huzur vermeyen Şarkın büyülü güzelleri gibidir, surlarının tepesinden onların imkânsız mücadelelerini kayıtsızca izlemekle yetinir. Yalnız On Beşinci yüzyılın ortalarında, Şehirlerin Kraliçesinin etrafı farklı ve zinde bir güç tarafından kuşatılmaya başlanır. Bu kuşatmanın başında, dönüşü olmayan yola çıtığının bilincinde, oldukça genç ve hırslı bir komutan bulunmaktadır. Ya bu şehri alacak ya da her şeyini kaybedecektir. Bütün dünyanın gözü önünde, iki tarafın da lügatinde, merhamet kelimesinin olmadığı bir savaşa girişilir ve sonunda yirmili yaşlarda bulunan bu tutkulu komutan, isminin önüne bir Fatih unvanını almış olarak, büyük savaştan muzaffer çıkar. Avrupa için dünyanın en karanlık günü olarak kabul edilir, aşlmaz surlarına güvendikleri kutsal şehirlerinin burçlarında Türklerin bayraklarının dalgalandığı tarih. 
Genç Fatih, hayallerindeki şehre kavuşmanın mutluluğunu yaşarken onu yeniden imar etme gayretiyle İstanbul dışından binlerce sanatkârı, şehre davet eder. İslam'ın gölgesinde, yeni bir medeniyet anlayışıyla zaten güzel olan şehir daha da güzelleştirilir. Allah'ın kendilerini yarattı̆̆ yerde durmayan, sürekli mekân ve başkent değiştiren Türk milleti, İstanbul'un fethiyle sanki yerleşik hayata geçmiş gibidir. Payitaht yaptığ 1 yedi tepeli şehri, kendisine merkez kabul ederek, bütün sanatsal ve kültürel gelişmelerini ya bu şehrin içinde ya da ona yakın yerlerde sürdürür.

\title{
2.2.2. İstanbul Panoraması:
}

Avrupalı gezginler için gezilip görülmesi gereken yerlerin başında olan İstanbul, tarihinin hiçbir döneminde ziyaretçisiz kalmaz. Gelen misafirlerini de her zaman derinden etkilemeyi başarır. Onu gören İstanbul sevdalılarının üzerinde olumlu veya olumsuz hep ciddi etkiler bırakır. Kimi minarelerle süslü semalarında umduğundan fazlasını bulduğunu belirtir; kimisi de kirli bakımsız sokaklarında kaybolarak, hayal kırıklıklarıyla döner, ülkesine. Ama hepsi de İstanbul'un tarihsel süreç içerisinde yaşadığı evrelere daha yakından şahit olmamızı sağlayarak, şüphesiz onu daha fazla sevmemize yardımcı olur:

\begin{abstract}
"Seyyahların İstanbul'u surlarıyla, saraylarıla, kilise ve camileriyle, yalıları ve köprüleriyle bizim şimdi yaşamakta olduğumuz İstanbul'dur. Ne var ki, İstanbul'u ziyaret etmiş olan seyyahlar ölümsüz sayfaları ile asırların tozunu silmekte; “yerde her taşını öpüp başımıza koymak istediğimiz” İstanbul, onlar sayesinde, gözlerimizin önünde katmerli bir gül gibi yaprak yaprak açılmaktadır. Yabancı seyyahlar bazen hayran kalarak, bazen haset ederek, bazen bilgileriyle bizi aydınlatarak, bazen cehalet ve dikkatsizlikleriyle bizi şaşırtarak; binlerce, yüzlerce yl öncesinin İstanbul'unu ve İstanbullularını bugüne taşımaktadırlar. Hakkında en fazla kitap yazılan dünya şehirlerinden biri olan İstanbul'un hafızasına, kaleme aldıkları eserlerle katkıda bulunan bütün o geçmiş zaman insanlarına, gönül aynalarına yansıyan İstanbul ve İstanbullularla bizi tanıştırdıkları ve "Şehirlerin Sultanı”nı bize daha çok sevdirdikleri için minnet duyuyoruz." (Meriç 2010:15).
\end{abstract}

Şehrin, ziyaretçilerini fazla etkileyen yönlerinden birisi, onun tepeler üzerine kurulmuş konumu olur. Birçok Avrupa başkenti, düzlükler üzerine kurulduğu için güzelliklerini, İstanbul gibi hemen kolayca sunamaz, ziyaretçilerine. Boğaziçi'nin kıyllarındaki köşkleriyle, muhteşem camilerin göklere yükselen zarif minareleriyle, serviler arasına saklanmış kabristanlarıyla şehrin görüntüsü, tasvir edilmesi zor bir mekânda bulundukları hissi uyandırabilmektedir, çoğunlukla uzaktan seyreden yabancı gözlerde.

On dokuzuncu asırla birlikte büyük bir ziyaretçi ordusunun, deniz veya kara yoluyla türlü güçlükleri göze alarak, İstanbul'a doğru bir yöneliş başlattıklarına şahit olunur. Önceki dönemlerde, buraları ziyaret eden ressamlar, sanatkârlar ve seyahatname yazarları, gerçeklerden ziyade, arasına fantezilerin karıştığı İstanbul imajının daha fazla merak uyandıracağını çabuk keşfederek, şehri o kadar büyülü ve abartılı pazarlarlar ki, Avrupa kamuoyuna, bunun doğal sonucu olarak, bir İstanbul masalının ve tutkusunun oluşmasını sağlarlar. Osmanlı saraylarının ve haremlerinin gizli dünyaları, örtüsüyle kendini görünmez kılan Şarkın kadınları ve korkunç Türkün, türlü cezalarla, işkencelerle, insanları -özellikle de harem kadınlarını- boğdurup denize atmalarla iç içe geçmişs şiddetli yaşamı, bu dünyaya olan ilgiyi arttıran belli başlı nedenlerdendir (Wheatcroft 1993:138-139).

Denizden gelen Avrupalı seyyahları, İstanbul'un uzaktan görünen manzarası adeta büyüler. Sarayın bulunduğu noktadan Haliç’e doğru süzülen geminin güvertesinde, kendi ülkelerinde gördükleri manzaradan tamamen farklı bir dünyayla yüz yüze gelen romantik dönem seyyahları; minarelerle, kubbelerle, kulelerle iç içe geçmiş, tepeler üzerine kurulmuş şehir karşısında, hayranlıklarını gizleyemezler. On Dokuzuncu asrın ilk yarısında Osmanlı coğrafyasını dolaşan seyyah C. Macfarlane de diğer birçok Avrupalı gezgin gibi deniz yoluyla geldiği İstanbul'un manzarası karşısında hayranlığını dile 
getirmekten uzak kalamaz ve Avrupa belleğinde derin izleri olan bu tarihsel şehrin panoramasını çizmeye çalışacağını belirtir ve oldukça da süslü cümleler kurmaktan uzak kalamaz:

\begin{abstract}
“Marmara Denizi'nin Avrupa kıyılarından girildiğinde İstanbul, saray manzaralarına gelene kadar yeni bir şey bahşetmez yabancı gözlere. Haliç'e demir atan gemiden bakıldığında da gümüş kubbeli camilerinde bir ağırlık ve kasvet yüklüdür. Hilalli minarelerde de aynı sönüklük ve kasvet hüküm sürer. Birbirlerine uyumlu bir şekilde yerleşik olmayan yedi tepeleriyle de insanda ilk olarak bir hayal kırıklığı yaratır bu ölümsüz şehir. Beyoğlu'nun ve Kasımpaşa'nın sırtları ise bütün güzelliklerini yapay düzenlemelere, kızılboyalı evlere, yoğun serviliklere ve canlı yeşilliklerine borçludur. Sarp kıyılarla çevrili olan Boğaz ve etkileyici şahane altın boynuz bu şehrin vazgeçilmezleridir.
\end{abstract}

Sanki seyir âşıklarını mutlu etmek için Cenevizliler tarafından Galata ile Pera arasındaki bir tepeye (savunma amaciyla inşa edilen, daha sonra da Türkler tarafindan yangın gözetleme kulesi olarak kullanılan) yapılan Galata Kulesi, baştanbaşa, bütün eşsiz İstanbul manzarasının seyredilebileceği en güzel yerdir. Kulenin tepesinden, İstanbul'un gözlerden uzak kalan gizli köşeleri, gözlerimizin önüne serilir. Topkapı Sarayından Eyüb’ün bütün mahalleleri, Tarihi surlardan Yedikule Zindanları, engin bir manzaranın ortasında yükselen minareler, kubbeler, Ayasofya'nın gururlu kubbesi, Hipodromun tam ortasında görkemli ve heybetli yükseltisiyle Sultanahmet durmaktadır. Bu görkemli kuleden sadece şehrin o anki manzarası seyredilmez; belki görünen manzaradan daha yoğun bir şekilde Bizans ve Roma'ya ait tarihsel geçmişi de insanın hayal dünyasına doluşur. Kuleden biraz hareketle bu liman şehrinin Anadolu'ya doğru uzanan diğer bölümleri de görüş alanına girer. Ulu Dağ’ın karlı dorukları, servilerle kaplı Müslüman mezarlıkları, Boğaz boyunca serpiştirilmiş muhteşem köşkler, yalılar, kanalın içerisinde bir kayanın üzerinde beyaz duvarlarıyla dikkatleri üzerine çeken romantik kız kulesi, camileriyle, evleriyle, kabristanlarıyla dokunulacakmış gibi yakın gözüken ÜsküdarKadıköy, İstanbul'un güzelliğine güzellik katan yerlerdi.

Güneş, Trakya'nın tepelerinin arkasından kaybolurken, İstanbul'un içerisinde bulunduğu manzaranın tasvirini yapabilmek dilin ve sanatkârlığın gücüyle imkânsız gibidir. Boğaz'da ve Haliç’te dolaşan kayıklar ise insan eliyle yapılan minarelerden sonra en güzel ikinci nesnelerdir. Topkapı Sarayı'nın ve etrafındaki yapıların beyaz duvarlarına karşılık servilerin ve diğer ağaçların koyu yeşillikleri ve damların kubbelerinin kurşuni ağırlıkları, akşamın bu saatinde bir renk harmonisi sunmaktaydı. Boğazın karşı tarafında, Topkapı Sarayı'nın da hemen hemen karşı tarafında kabul edebileceğimiz, Asya kıyılarından denize firlamış gibi duran Fenerbahçe hayallerin ötesinde bir güzellik sunuyordu şehrin siluetine.”(Macfarlane 1829:386-390).13

Seyyahların gezi rotalarında, Topkapı Sarayı, Ayasofya ve camiler önemli yer işgal eder. Bu yerlerin güzellikleri karşısında etkilenmeyen yok gibidir. Fakat şehrin sokakları, caddeleri, dükkânları bir keşmekeşliğin ve eskimişliğin içerisinde harap görünür. İstanbul, tarih boyunca iki büyük felaketi olan yangınlar ve depremlerden kendisini koruyabilecek bir yapıya da sahip olmadığ için tarihsel güzellikleri yok olmayla yüz yüzedir. Yapı itibariyle tembel olan Türkler, depremlerin, yangınların çirkin kalıntılarına yıllarca dokunmayarak güzel şehrin daha da kötü gözükmesine sebep olur. Bu iki büyük felaket yüzünden şehirde eski tarihli evlere rastlayabilmek ise oldukça güçtür.

Gündüzleri şehrin karmaşık sokakları, renkli, hareketli, gürültülü ve canlı olmasına rağmen geceleri ayrı bir sessizliğe bürünür, Şarkın payitahtı. Sokak aydınlatmaları da iyi olmayan İstanbul'un üzerine derin, ürkütücü bir karanlık çöker. Bu derin karanlığı ve büyük sessizliği zaman zaman acı bir çığlık, sevimsiz bir aydınlık böler: Yangın var!

Letters from Constantinople 1897, yazarı Georgina Adelaide Müller, sisli bir mayıs sabahında, yolcusu epeyce kalabalık gemiyle adaları seyrederek İstanbul'a doğru yaklaşır. Gemideki Arnavut ve Karadağlı yolcuların görüntüleri, insana güven vermekten çok uzaktır. Yatak-yorganlarını yanında taşıyan bu yolcular, kumarla, çeşitli kart oyunlarıyla vakitlerini geçirirler. Kadınlar, zamanlarını daha çok çocuklarıyla ilgilenerek ve erkeklerden ayrı oturarak geçirmektedir, görüntüleri erkeklere göre daha sevimli, sempatiktir. Birinci sinıf gemi yolcuları, yolculuk boyunca bu pejmürde, yabani görünüşlü

13 Macfarlane'den yapılan bu alıntı İngilizce aslından Türkçeye tarafımızdan tercüme edilmiștir. 
yolcuların aralarına karışmamaya ayrı bir özen gösterir, hatta gemi mürettebatı tarafından da onların yapabilecekleri hırsızlıklara karşı da uyarılırlar.

Yazar, adalardan İstanbul'a doğru uzaklaşırken, onlar hakkında bilgiler vermeyi de ihmal etmez. Dokuz adadan sadece dört tanesinde, insanlar ikamet etmektedir. Adaların içerisinde en güzeli Büyükada, bir vadiyle bölünmüş iki tepeden oluşmaktadır. Çam ağaçlarıyla kaplı ada, denize doğru kurulmuş, rengârenk çiçeklerin ortasındaki güzel villalarıyla ada sakinlerine ve ziyaretçilerine huzurlu bir yaşam sunar. Ayrıca İstanbul'un bunaltıcı sıcaklarında, sığınılacak hoş bir limandır, çoğu insan için de.

İstanbul sevdalısı birçok seyyah gibi Letters from Constantinople, 1897, kitabının yazarı da Sarayburnu'nu geçtikten sonra temaşa ettiği İstanbul manzarası karşısında, duygularını kontrol etmekte hayli zorlanarak, şairane bir üslupla, gördüklerini, kalemi aracılığıyla ölümsüzleştirmeye çalışır. Her birisi camilerle süslenmiş yedi tepesiyle, yazarı keşfe davet etmektedir, Şehirlerin Kraliçesi. Bu şehir, günün her saatinde ayrı bir güzeldir; öğle güneşi ayrı, ikindi güneşi ayrı, akşamın kızıllığı ayrı bir güzellik katar güzelliğine. Ama onu en fala güzelleştiren, büyülü bir atmosfer içerisindeymiş gibi mehtaplı gecelerde parıldayan görüntüsüdür. Çoğu Avrupa şehrinin güzelliklerini de üzerinde toplamış olan İstanbul'un bütün cazibesiyle doya doya temaşa edilebileceği en güzel yer, hiç şüphesiz Marmara Denizidir:

\begin{abstract}
“Marmara'dan İstanbul'un görüntüsü, her tür ışı altında ve günün her saatinde esssiz bir güzellik içerisindedir. Alçak tepelerin o zarif hatları, o renk cümbüşü, o görkemli yapılar Stokholm, Venedik ve Napoli Koyu'nun güzelliklerinin tamamını kendinde toplamıştır. Günışığının etrafa yayılmasıyla renklerin çeşitliliği göz kamaştırıcıdır. Gözünüz camilerin etrafını çevreleyen küçük henüz dolmamış mezarlıkların olduğunu haber veren neredeyse simsiyah servilerin aksine kar beyazı minareleriyle o camiden başka bir camiye dolaşıp durur.” (Müller 1897:5).
\end{abstract}

Üzerinde yaşayanlar, onu ne kadar çirkinleştirmeye çalışırsa çalışsın tabiatın ve tarihin ona verdiği güzellikler, öyle kolay kolay yok edilebilecek cinsten değildir. İstanbul'un bu güzellikleri sadece G. Adelaide Müller’i etkilememiştir, onunla birlikte yolculuğa çıan eşi Max Müller de payitahtın cazibesi karşısında kayıtsız kalamaz ve 19. asrın sonundaki İstanbul'u kelimelerin yardımıyla okuyucularına resmeder. Boğazdan Haliç’e doğru süzülürken karşılaşlan manzara resmedilemeyecek kadar olağanüstüdür. Mayıstan itibaren ışıklarını bu coğrafyaya bol bol sunan Güneşin katkılarıyla manzaraya parıltılı bir muhteşemlik de eşlik eder. Sarayların, gökyüzüne uzanan zarif minareleriyle camilerin, yeşil balkonları, kahverengimsi çatılarının renkleriyle evlerin, denize yansıyan görüntüleriyle; bunlara ilaveten denizin üzerinde her renkten yelkenlinin oluşturduğu renk cümbüşü ve uzaktaki tepelerin yeşile bürünmüş manzaralarıyla insana görsel bir şölen sunan böyle bir şehri, dünyanın başka bir yerinde görebilmek imkânsızdır.

\title{
2.2.3. İstanbul'un Kaybolan Güzellikleri:
}

İmparatorluğun zayıflamasına paralel olarak İstanbul sokakları pek iç açıcı değildir. Kirli, tozlu, çamurlu, pis kokulu ve gürültülerle dolu karmakarışık halleriyle ziyaretçilerini fazla memnun eden bir hali yoktur. Denizden yaklaşılırken görülen o güzel manzaraların yerini, savaşlarla, bitmeyen problemlerle uğraşan İmparatorluğun fakirlik içerisinde çırpınan gerçek yüzü alır.

Geminin limana yanaşmasıyla temaşasına doyum olmayan güzel manzara kaybolur ve İstanbul'un kozmopolit yaşamıyla yüz yüze kalır, yazar. Her taraftan farklı dillerle yolcu kapmaya çalışan insanların koşuşturması içerisinde, kendisi için ayrılan atlı arabaya binerek Pera'ya doğru yol alır. Bu arada karşı kıyıdaki (Üsküdar'da) İngiliz kabristanını hatırlayarak iç geçirir: -Boğazın öbür yakasında ise Kırım 
Savaşı'nın amılarıyla ve o eski günlerden tanıdığımız birçok kimsenin son uykularını uyuduğu o güzel İngiliz kabristanıyla Üsküdar duruyordu.- Yol boyunca etrafı seyrederek ilerleyen yazarın dikkatini, sokaklarda başıboş dolaşan köpekler çeker. Genelde sarı- kahverengi olan bu köpekler, gün boyunca miskin miskin etrafta dolaşır veya uyur, geceleri ise şehrin karanlık sokaklarının tek hakimi onlardır. İstanbul'un köpeklerle dolu sokakları, tarih boyunca şehre gelen bütün seyyahların dikkatlerini çeker; kimileri nefret eder, kimileri ise onların şehrin -çöpleri ve at leşlerini yiyerek- doğal temizlikçileri olduklarını belirtir (Şahin 2007:106-110).

Seyyahların birçoğu köpeklere ve diğer hayvanlara karşı Türklerin çok hoşgörülü ve iyiliklerle dolu yaklaşımlarını onların dinlerinden kaynaklandığını belirtirler. Hayvanlara karşı böyle hassas ve merhametli olan bir milletin, insanlara karşı neden bu kadar merhametsiz olduklarına bir anlam veremezler (Wheatcroft 1995:158). İzmir'den Bergama'ya doğru yola çıkan gezgin Macfarlane'nin de Müslüman tebaanın hayvanlarla olan iyi ilişkileri dikkatinden kaçmaz. Leyleğin bu toplumla kurmuş olduğu sıcak ilişki onu hayrete düşürür:

\begin{abstract}
"İnsan hayatına ve kanına fazla önem vermeyen bu millet, hayvanlara karşı aşırı merhametlidir. Leyleğin ise sanki onlarla ayrı bir kutsal anlaşması var gibidir. Bu hayvan Müslüman halkın içinde özgür ve korkusuzca dolaşır, bağ ve bahçelerde hep onların yanı başındadır. Hatta yuvasını bile hep Müslümanların olduğu kutsal mekânlara ve evlerin üzerine yapar, adeta gayri-Müslimlerin kutsal yerlerine ve oturdukları semtlere hiç uğramaz." (Macfarlane)
\end{abstract}

A. Müller'den yarım asır önce İstanbul'a gelen İngiliz gezgin C. Macfarlane de onun gibi bu şehrin sokaklarının karmaşasını dile getirir. Tanzimat reformlarıyla Türkiye'de birçok ilerlemenin olduğunu dinleyen, okuyan yazar, vapurdan Tophane'nin pis çamurlu iskelesine iner inmez ilk şoku yaşar. Etraftaki kargaşaya perişanlığa bakar bakmaz okuduklarının ve duyduklarının hiç de doğru olmadığını anlamakta gecikmez. Avrupa'da oluşturulan imajla hayalleri süsleyen İmparatorluğun başkentinin sokakları, düzensizlik ve kirlilik içerisindedir. Sokakları ve döşenen taşları da karman çormandır. İnsanları ise dar sokaklardan gelip geçenlere yol vermeyen çirkin görünüşlü kişilerdir. Sokaklarda odun ve kereste taşıyan at ve eşekler bolca vardır. Kalabalıklaşmış olan sokaklar, caddeler ${ }^{1828}$ 'de görüldüğ̈̈nden daha kötüdür. Hiç temizlenmeyen kötü kokulu yollar, caddeler, yangınlardan arta kalan kötü görüntülü yı̆̆ınlar, köpek ve fare leşleri, 1848 yılı başkent manzaralarıdır. Özellikle geceleri aralıksız duyulan sahipsiz köpeklerin havlamaları, ulumaları, satıcıların bitmeyen çı̆̆ırtkanlıkları, sivrisinek benzeri haşeratların deliksiz uykuya müsaade etmeyen rahatsılılıları ve günün her saati işitilebilecek olan "Yangın var! Yangın var!" çı̆̆lıkları, insanda ben işte İstanbul'dayım düşüncesi uyandırmaktadır.

Max Müller'e göre İstanbul Eski Bizans olmaktan çok uzaktır. Yarı Doğulu yarı Batılı haliyle dünyanın en güzel yerlerinden biridir. Bu güzelliğiyle bütün komşularının iştahını kabartmaktadır. Her ne kadar onun sahipleri "Hasta Adam" olsalar da güçlü, dayanıklı ve ne yapacakları belli olmayan kişiler oldukları için yüz yıllardır sahip oldukları payitahtlarından kolay kolay vazgeçmeyeceklerdir. "Saf Türk sağlam ve sarsllmazdır, dört yüz yıldır kendisinin saydığı şeyden vazgeçeceği acı bir sondan önce dövüşmeye kararlıdır."(Müller 1897:20). Cümlesiyle Max Müller, İstanbul'un Batılı güçler tarafından, zayıf Osmanlının elinden alınacağından emin gibidir, Türklerin ise çaresizlik içerisinde yenilmeleri kesin bir savaştan başka yapacakları hiçbir şey yoktur.

\title{
2.3. Osmanlı Kadını
}

\subsubsection{Avrupa'nın Osmanlı Kadınına Bakışının Tarihsel Boyutu}


Avrupa’nın Doğulu -Müslüman- kadına bakışı, tarihsel süreç içerisinde değişen, dönüşen bir olgu olarak karşımıza çıkar. Batı literatüründe, İslam dünyasının kadınlarının en fazla görünür olduğu dönem, Avrupa'nın yükselişine paralel olarak daha çok On Dokuzuncu yüzyıl olur. Daha önceki çağlarda özellikle Ortaçağda- Batıyı, Doğulu kadından ziyade; Doğu'nun kendisi meşgul etmektedir. Onları "Bu dinin mensuplarının nasıl bu kadar ilerleme gösterebildiler?” sorusunun cevabı daha çok ilgilendirmektedir.

Karşılarındaki güçlü Şarkla birlikte, edebi metinlerde çok fazla yer kaplamayan bu bölgenin kadınları da güçlü kişiliklere sahip, tehlikeli insanlardır ve mümkün olduğunca da Doğu yolcusu Batılı kahramanlar, o siyah, iri gözlü, sihirlerle donatılmış, tutkulu kadınların kendilerine verebileceği zararlardan korunma yollarına bakmalıdır. Daha sonraki devirlerde göreceğimiz, Batının ezilen Doğulu kadınları kurtarma, özgürleştirme çabalarından, girişimlerinden, örtüden, haremlerden henüz eser yoktur; tam aksine bu güçlü ülkelerin güçlü kadınlarını, kontrol altında tutabilme teşebbüsleri daha fazla dikkatleri çeker.

Şarkın Ortaçağdaki kadınları, ne kadar güçlü olurlarsa olsunlar yine de kadınsı duygusallıklardan fazla uzak kalamaz; ülkelerine gelen Avrupalı kahramanlara veya kral olan babasının zindanlarına esir düşen yakışıklı beyaz adamlara, âşık olmaktan kendini kurtaramaz. Aşkı uğruna her şeyi göze alacak olan Doğu'nun güçlü kadınları, babalarına ve içinden çıktıkları topluma karşı Batılı âşıklarının yanında hiç düşünmeden durarak onları, Şarkın zorbalıklarından kurtarmak uğruna, gerekirse dinlerini bile değiştirerek toplumlarını terk ederler. Batının görmek istediği şekle bürünüp bir Hıristiyan, bir Avrupalı gibi yaşamaya başlayarak daha da güzelleşir ve o kültürün parçası olur (Khaf 2006:5). Aşkı için büyük fedakârlıkları göze alabilen hayli romantik Şark kadını imajı, uzunca bir süre Batılı edebi eserlerin ana temaları arasında kendisine konforlu bir yer bulur.

Avrupa'nın keşifler ve ticari yayılmalarıyla büyüme sürecinde; Müslüman kadın imajının hem eski dönemlerin izlerini taşıdığı hem de yeni bir boyut kazandığı gözlerden kaçmaz. Sanki bu dönemde, daha sonraki süreçte, kurtarıcı olacak Batılı erkekleri bekleyen Doğulu kadınlar için bir zemin hazırlama girişimi içerisindedir, Batı yazını:

\begin{abstract}
“...Ortaçă̆ hikâyelerinde yer alan saldırgan ve coşkun Müslüman kraliçeler ve güçlü-şirret kadınlar artık görünmez olmuştur. Avrupa Rönesans edebiyatında Müslüman kadın, mitler arasındadır. Bazı metinlerde, Müslüman dişi karakter, eski kraliçelerin 'şehvet düşkünü’ özelliklerini taşır; bazılarında ise, tam anlamıyla daha sonraları ortaya çıkacak çaresiz genç kız temsilinin izlerine rastlanır. Metinlerin çoğunda kahramanımız, Batılı hemcinsleriyle aynı cinsiyet sınırlamasına maruz kalır ve bu da “Ötekilik”ten ziyade, benzerlik ve “aldırmazlık” anlamında bir işlev görür.” (Khaf 2006:6).
\end{abstract}

On yedinci ve on sekizinci yüzyıllara gelindiğinde, örtü ve harem odaları, Şark kadınının vazgeçilmeyen birer parçaları olur. Ve artık Şarklı kadın, örtünün ve haremlerin karanlık dünyalarına hapsedilmiş birer odalık veya cariye olarak zavallıdan başka bir şey değildir. Önceden var olan saldırganlık, aktiflik, cesurluk gibi özelliklerini, teker teker kaybederek sesi çıkamayan pasif bir nesneye dönüşür, sarayların ve haremlerin aşılması zor duvarlarının derinliklerinde. Bu duvarların gerisinde ve peçesinin içerisinde kaybolmuş esrarlı kadın imajı, uzunca bir süre, Batılı erkeklerin zihinlerini meşgul edecek erotik bir nesneye dönüşür.

Batı’nın, Doğuda yakın komşuları olan İslam ülkelerindeki hâkimiyetini, zaman içerisinde arttırmasına paralel olarak o bölgenin kadınlarına olan ilgide büyük bir yoğunluk görülür. Batılı romantiklerin önemli görevlerinin başında; On Dokuzuncu yüzylla birlikte, zalim, çirkin, despot erkekler tarafindan 
haremlerin ${ }^{14}$ ve peçelerin karanlı dünyalarna hapsedilen, zayıf, sessiz, kaderlerine razı olmuş, köleleştirilmiş, cinsel hazlarla dolu, siyah gür saçları, karakaşları ve kirpikleriyle sıra dışı gizemli güzellikleri olan Doğulu kadınları, kurtarabilmek gelecektir. Bu uğurda mücadeleye girmekten de hiç kaçınmayacaktır:

\begin{abstract}
"Yok, edilmesi mümkün olmayan farklılık ve egzotiklik, yoğun cinsellik, aşırı süslenme ve fetiş nesnelere yakınlık; son olarak hapsedilme, köleleştirilme, cinsler arası mekânsal ayrım, susturulma, görünmez kılınma şeklinde kendisini gösteren güçsüzlük. Bu unsurlar, genellikle örtü ve/veya harem aracılığıyla elde daima hazır tutulan bir anlatı türü içinde tezahür eder. Hikâyenin temel çizgisi, çoğunlukla, Romantik kahraman ve Müslüman kadını sahiplenmek üzere yapılan savaştır. Bu, daha ziyade harem duvarına ve/veya kadın peçesine nüfuz etmek ve onun bedenini görme hakkına sahip olmak üzere yapılan bir mücadeledir.” (Kahf 2006:10).
\end{abstract}

Peçe ve peçeli kadın metaforu, Avrupalı için keşfedilmesi gerekli, gizli karanlık bir dünyadan başka bir şey olmayarak onun zihnini hep meşgul eder. Peçe; sadece Müslüman kadının yüzünü kapatan bir nesne olmaktan çok daha ileri anlamlar kazanarak onun gizli dünyasının önünde, katmanlı bir engele dönüşür. Müslüman kadının peçesinin gerisindeki dünyayı tanımadan, Doğuyu tanıma girişimlerinin tamamlanamayacağı inancına sahip Batılı düşünce, enerjilerinin büyük bir bölümünü, bu yöne kanalize ederek görünmeden görebilen kadınların dünyasını, gün yüzüne çıkarmanın yollarını arar. Çünkü bu kadar kapalı ve gizlenen bir dünyanın, meraklı Batılı maceraperestlerin, gezginlerin ilgilerini kat kat arttırmaları kaçınılmaz olur:

\begin{abstract}
"Saydam olmayan bu peçe yardımıyla, Doğulu kadının kendini Batılı bakışa teslim etmediği düşünülür ve dolayısıyla peçenin arkasında bir şey gizlendiği tahayyül edilir. Peçe bir maske olarak görüldüğünden, Doğulu kadın bir sırra dönüşür. Bu tür bir söylemsel yapı, bu kadınların gerçek doğasının gizlendiği, hakikatlerinin maskelendiği ve sahte, aldatıcı bir görünüşe sahip oldukları varsayımını doğurur. Demek ki bu kadınlar göründüklerinden başka bir şeydirler.” (Yeğenoğlu 2003:60-61).
\end{abstract}

Doğuyu tam anlamıla keşfedebilmenin önündeki en büyük engel, Batılı erkek özne için peçeyle haremlerin yüksek duvarlarıdır. Bu engelleri aşabilmek ise oldukça zor bir iştir: Çünkü Doğulu Müslüman erkekler -özellikle de Türkler-, yabancıları, hanımlarının bulunduğu yerlere sokmak şöyle dursun; onlarla ilgili en küçük sohbetlere bile sıcak bakmamaktadır. Şark kadının bu kadar kapalı ve ulaşılması zor bir dünyasının olması, bu alana olan ilgiyi daha fazla arttırır. Göremediği bu gizemler dünyasına duyulan yüksek istek, hayali ve hasta bir bakış açısıyla oluşturulmuş abartılı bir evreni ortaya çıkarır, ressamların tablolarında veya seyyahların satırlarında.

Şarkın en ihtişamlı, gerçek yaşamlarının, erkeklerin ulaşamayacağı evlerin içerisinde, tembel kadınların uzanıp, nargilelerini tüttürürken ve tatlı şerbetlerini yudumlarlarken oluşan renkli dünyalarda gizli olduğu inancıyla o yerlere ulaşmanın kesin yolları araştırılır. Bu konuda Avrupalı erkek öznenin yardımına, eksik olan Doğulu bilgilerini tamamlamak için kadın seyyahlar gönüllü koşarlar. Onlar için Doğunun en mahrem köşelerinin kapıları sonuna kadar açılır. Avrupalı hemcinsleri sayesinde gizemlerinin çözüldüğüne inanılan Doğulu kadınlar için yeni bir süreç başlayacaktı: Dinlerinden ve despot erkeklerden kaynaklanan, baskılarla dolu bu hayattan, Şarkın kaderine razı olmuş, edilgen ruhlu kadınlarını kurtarabilmek. Bunun yolunun da -onları karanlıklara gömdüğüne ve güzelliklerini anlamsızlaştırdıklarına inandıkları- peçeyi yırtmaktan ve haremin o yüksek duvarlarını yıkmaktan

14 "Batının düşüncesindeki despot Doğu, sırlarını çok sıkı koruma altına alıyordu. Doğu resimlerinde en çok görülen bir figür de bir haremi, sarayı, camiyi ya da tüm Doğuyu koruyan, girişleri kapatan bir kara adamdır. ..... Adamın ifadesi itici ve acımasızdır, hançeri, baltası ve tabancası ürkütücüdür. Giysisinin rengi bile ateş gibidir; yakına gelenleri uyarmaktadır, adeta. Harem kapısını tamamlayan bir demirbaş gibidir; o olmadan sıradan bir geçit olacakken, onun varlığı ile sızılması olanaksızlaşmıştır. Bu geçidin ardındaki kadınlar, bırakın dokunmayı asla görülemezler. İşte, Avrupalı gözüyle harem budur: Kıskançlıkla dışlarken, sonsuz zevkler sunduğu için yararlandığı haremdir”. (Kabbani 1986: 96.) 
geçtiğine inanırlar. Osmanlı Batılılaştıkça bu sorunun da ortadan kalkacağı görüşünde birleşir, kurtarıcı görevleri olduğuna inanan Avrupa düşüncesi

\subsubsection{Osmanlı Kadınının Saklı Dünyası}

Seyyahlar, İslam ülkesinin kadınları hakkında genel bir görüşe sahip olmakla birlikte, Osmanlı kadınları için de ayrı bir pencere açarlar Avrupalı takipçilerine. Bu görüşlerin objektiflikten hayli uzak, erotizm ve cinsellikle fazlaca yoğrulmuş olduğu da gözlerden kaçmaz. Gezginlerin bakış açıları doğrultusunda şekillenen bir Osmanlı kadını dünyası oluşturulur. Bu dünyanın kadınları bazı yazarlara göre; "çok cahil, çocuklarmı iyi eğitemeyen, zevksiz giyinen, evlerine hapsedilmiş, çok küçük yaşlarda eşlerini dahi görmeden evlenen, zavall, mutsuz kimselerdir”. Zamanlarının çoğunu evlerinde veya hamamlarda süslenerek geçirirler. Gizli ve kapalı dünyalarında eşlerini aldatma gibi ahlaksızlıklara da rastlanabilmektedir (Şahin 2007:302).

Osmanlı kadınlarının olumsuz yönlerine seyahatnamelerde yer verilmesine rağmen olumlu yönlerine de geniş sayfalar ayrılır Onlar, mülk edinme ve ekonomik özgürlük bakımından, Batılı hemcinslerine göre daha şanslı konumdadır, çünkü Batılı kadınların o dönemlerde mülk edinme haklarının olmadı $\breve{g} ı$ ve ekonomik olarak eşlerine muhtaç bir hayatlarının olduğu belirtilir. Dışarıya karşı sert ve kaba olan Osmanlı erkekleri, eşlerine karşı genellikle çok sevecen, yumuşak huyludur.

Giydikleri türlü renkteki elbiseleriyle, kınalı elleriyle, lüleli saçlarıyla, bir ceylanınkini andıran iri, siyah gözleriyle ve pürüzsüz, yumuşak ciltleriyle insanı büyüleyecek kadar güzel olan bu kadınlar, açlk havalarda gezmeyi, mesire yerlerinde eğlenmeyi çok sever. Yabancı erkeklere yüzlerini göstermekten hoşlanmadıkları için de onları gördükleri zaman, farklı taraflara dönerek yüzlerini saklarlar. Eşlerine, çocuklarına ve ailesine aşırı derecede bağlı olmaları, en önemli meziyetlerindendir.

Avrupa'daki yakınları aracılığıyla veya dergiler sayesinde modayı takip edenleri ve o tarzda giyinenleri de az değildir. Misafir ağırlamayı, misafirliğe gitmeyi çok severler, özellikle Avrupalı kadın misafirlerini ağırlamayı ve onlara iade-i ziyaret yapmayı çok seven Osmanlı harem eşrafı, bu ziyaretlerde uşakhizmetçi de olsa erkeğin ortada olmamasına ayrı bir özen gösterir (Şahin 2007:299-309).

Erkek anlatılarının hâkim olduğu Doğulu kadınların dünyasına, çok gür, etkili, gerçekçi bir ses, Leydi Montagu'nun 18. asrın ilk çeyreğinde "Türk Mektupları" adlı eseriyle girer. Girdiği andan itibaren de etkisi çok fazla olur. Erkekler tarafından realiteden uzak, hayali imajlarla oluşturulan Osmanlı kadınının gizli dünyası, gerçek boyutlarıyla ve kendisinden önce yaratılan imajlara bir başkaldırı olarak Batı literatüründe yerini alır ve dikkatleri fazlasıyla üzerine çeker. Türk Mektupları, Osmanlı kadını ile ilgili ön yargıları bir bir yıkarken, onların sanıldığının aksine daha realist, daha kadınca ve daha mutlu bir hayatlarının olduğunu özellikle vurgular. İlaveten, sürekli bir ruhlarının olmadığı belirtilen bu kadınların, önyargısız bakmayı bilenler için çok ince ruhlarının olduğunu da belirtmekten geri durmaz. Osmanlı kadınların dünyaları, kendisinden önceki erkek yazarların sürekli vurguladıklarının aksine, Avrupalı hemcinslerinin yaşantılarından ve eğlence tarzlarından fazlaca uzak olmayan bir yaşantıdır (Kalın 2016:338-342).

Erkek yazarların sabit bir fikirle çokça vurguladıkları, peçeyle özgürlüğü kısıtlanmış kadın imajı, Leydi Montagu ile yeni bir boyut ve anlayış kazanır. Ona göre peçesine bürünmüş kadın, İngiliz kadınlarına göre daha özgürdür; çünkü o, örtüsünün ona sağladığı avantajla istediği her şeyi yapabilir, tanınma korkusu bile olmadan. Bunun yanında haremdeki kadınların yaşantılarının da pek Avrupa'da bilindiği 
gibi olmadığını, kendi ülkelerindeki gibi tek eşliliğin bu topraklarda da özellikle tercih edildiğini, Sultanın hareminin ise genelde bütün krallıklarda rastlanabilinecek mekânlardan farklı bir yönünün olmadığını belirtir. Ayrıca Osmanlıda üst gelir gruplarından biriyle evli olan kadınlar daha mutlu, özgür bir hayat yaşarlar, isterlerse kendi servetlerini de oluşturma şanslarına sahiptirler.

Leydi Mary Montagu'nun mektuplarında, Avrupalı okuyucular, Doğu hakkında yazan diğer gezginlerin anlatımlarıyla alışmış oldukları egzotiklik ve görsel cinsel haz gibi konuları, boşuna aramış ve görmek istediklerini bulamamanın şaşkınlığını yaşamışlardır. Daha sonra da onun yazılarını, müellifinin hiç de kastetmediği alanlara çekerek yeniden yorumlama işine girişmişlerdir:

\begin{abstract}
“Leydi Mary’nin mektuplarının sonraki dönem okuyucuları, onun önde gelen kanaatlerini tamamıyla alaşağı edecek ve yazılarını, ardından gelen harem söyleminin penceresinden yorumlayacaktır. Mektuplardaki en özgün noktaları, müessif tuhaflıklar olarak değerlendirecek ve geri kalanını ise İngres'in Le Bain Turc tablosunda olduğu gibi görsel cinsel hazza dayalı romantik bayağılıkların hizmetine sunacaktır." (Khaf 2006: 153-154).
\end{abstract}

\title{
2.3.3. G. A. Müller ve Osmanlı Kadını
}

Leydi Mary'den yaklaşık bir buçuk asır sonra, Osmanlı kadınlarının örtülü dünyalarına, erkeklerin bakış açılarından tamamen farkı bir bakışla Georgina Adelaide Müller, yeni bir pencere açar. Osmanlı kadınlarına yaklaşımıyla, onları Batı kamuoyuna yansıtmasıyla sanki halefinin bir devamı gibidir. Adelaide Müller, önyargısız bir şekilde Osmanlının kapalı dünyasına girerken, bu dünyanın zarif, hoş görünüşlü, kendi küçük dünyalarında çoğu zaman da mutlu bir hayat yaşayan kadınlarına karşı derin bir sevgi taşımaktadır, kalbinde.

Çoğunluğunun evlilikleri, erkek ve kız tarafının kadın akrabalarınca ayarlanan Türk kadınları, günlerinin büyük bir bölümünü, evlerini veya bahçelerini çevreleyen yüksek duvarların arkasında geçirir. Kıskanç Türk erkekleri yüzünden, dış dünyadan kopuk bir hayatları olduğu için bütün enerjilerini, ev içerisinde, başta eşleri olmak üzere, evin diğer fertleri üzerinde çeşitli entrikalarla hâkimiyet kurmak için harcar ve genelde bu gayretlerinde de başarılı olurlar. Bundandır ki; Türkün gerçek yaşamı hakkında doğru bilgiye ulaşmak isteyen yabancıların onların harem yaşamını (ev içi yaşamlarını), çok dikkatli bir şekilde geniş geniş ele almalıdır.

Sultan II, Abdülhamid’in eğitim alanında yaptığı yenilikler ve açılan okullar sayesinde iyi eğitimler alabilen Türk kızları, belirli yaşa gelene kadar rahatlıkla dışarılara çıkabilme, babalarıyla istedikleri eğlence yerlerini gezebilme şanslarına sahiptir. Osmanlı toplumunda en şanslı, iyi eğitim almış güçlü kadınlar ise daha çok üst rütbeli kişilerin ve paşaların eşleridir. Bu kadınlar, Osmanlı sultanının gönülleri hoş eden bir eğlence malzemesi olmaktan ileriye geçemeyen eşlerine kıyasla oldukça iyi konumda ve entelektüel birikimleri yüksek olan birer hayat arkadaşıdır. Kocalarının servetlerinde ve mülklerinde de söz sahibi olmaktan da geri kalmazlar. Osmanlı toplumunda en güçlü kadınların valide sultanlar olduğu; çoğu zaman da oğulları yerine ülkeyi onların yönettiği tartışılmaz bir gerçektir (Müller 1897:126).

Osmanlının başkentinde, eşinin ünlü bir âlim, oğlunun ise İngiliz elçiliğinde görevli kâtip olması hasebiyle, üst düzey kabuller gören yazar, bulduğu bütün fırsatları değerlendirmekten uzak durmayarak en yüksek rütbeli şahısların ev içi hayatlarını, rahat rahat gözlemleme şansını yakalayabilir. İlk ziyaretini üst rütbeli bir nazırın haremine yapan Müller'in dikkatinden kaçmayan şey, hoş ve güzel bahçeli bu evin pencerelerinin bile zor görülebildiği yüksek duvarlarla çevrili ve bir hapishaneyi andırıyor olmasıdır. Bu duvarlarla çevrili evin içerisinde, Avrupalı misafiri ilk karşılayanlar, hoş giysileriyle beyaz ve siyah tenli 
hizmetçilerdir. Evin hanımefendisini beklemek için alındığı oda, muhteşem halılarla döşelidir; ama Türk hanımlarının günlerini ve hayatlarını geçirdiği bu odanın kitaplardan veya onların vakitlerini geçirebileceği faydalı nesnelerden uzak olması, dikkatli yazarın gözleminden uzak kalamaz ve büyük bir eksiklik olarak mektuplarının satırları arasında yerini alır, Avrupalı okuyucularına ulaştıılmak gayesiyle.

Osmanlı nazırının harem dairesinde, Avrupai tarzda giyinmiş, Fransızcası da düzgün olan küçük ve güzel gözlü bir hanımefendiyle karşılaşırız. Gözlerinin ışıl ışıl parlıyor olmasına rağmen, bu güzel gözler, evi ve bahçesi dışında fazla bir yeri görmekten çok uzaktır. Yılda birkaç kez ancak bu hapishaneyi andıran duvarların dışına çıkabilen şansız Osmanlı kadını, çocuğu da olmadığı için bütün sevgisini, bahçesindeki çiçeklere, kedilere ve köpeklere vermektedir. Resim ve müzikle ilgilenen, Fransız romanları okuyarak Batı hakkında fikir sahibi olan evin hanımefendisinin, Adelaide Müllere göre, mutlu olması imkânsızdır; çünkü o bu duvarlar arasında mutlu olamayacak kadar çok şey öğrenmiştir, hayat hakkında. Onun durumu, altın kafesin içerisinde nafile çırpınıp duran zavallı kuşun halinden pek de farklı olmayan bir manzaradır. Bu ifadelerden yola çıkarak, yazar için en mutlu Türk hanımlarının, Avrupa ve dış dünya hakkında en az bilgisi olanlar olduğu sonucuna varabiliriz.

Hareme eşlerin de gelmesiyle hep birlikte hoş bir sohbet ortamı oluşturmayı amaçlayan yazar, kadınların bu sohbetlerde sessiz kalmalarını, önceleri onların çekingenliklerine yorar. Fakat bu suskunluklarının aslında sohbetin konusu olan camileri, müzeleri, binaları hiç görmemelerinden kaynaklandığını öğrenir ve çevrelerinden bu kadar uzak kapalı bir hayatı hak etmediklerini düşünerek büyük bir üzüntüyle Nazırın hapishaneyi andıran yüksek duvarlarla kuşatılmış evinden ayrılır:

“... fakat biraz sonra fark ettim ki biz daha önce bu hanımın hiç görmediği ve göremeyeceği camiler ve binalar, müzedeki lahit ve haremdeki hazineler hakkında konuşuyorduk. Bu yüzden bizim sohbetimiz onun için anlaşılmaz olmalıydı. Her ne kadar eşlerinin kendilerine sağladığı zenginliğin tadını çıkarıyor görünseler de, bana huzursuz ve tatminsizmiş gibi gelen bu iki kadın için çok derin bir acıma duygusuyla buradan ayrıldım.” (Müller 1897:178).

Başka bir gün de Teşrifat Nazırı Münir Paşa’nın Boğaz'daki yalısında giden yazar, önce evin durumu hakkında okuyucuya bilgi verir. Kadınlarını yabancı gözlerden her zaman uzak tutmak, Türklerin genel özelliklerinden olduğu için normal evlerde yüksek duvarlarla kapatılan pencereler, yalılarda dışarıdan bakanın göremeyeceği ahşap kafeslerle kapatılır. Bu evin hanımı da diğer birçok Türk hanımı gibi gününün büyük bir bölümünü, evinde geçirmektedir. Hareketsiz yaşamlarından çoğu Türk kadınları gibi o da belli bir yaştan sonra kilolu biri olmaktan uzak kalamaz. Dışarı çıkarken giyilen, bütün vücudu baştan aşağı kapatan ferace, renkli renkli kumaşlardan yapılmasına rağmen, bütün çirkinliğiyle bu kadınların üzerlerine yapışan zevksiz bir elbise çeşididir.

G. A. Mülleri, oldukça mutlu eden yerlerden birisi ise meşhur ressam Hamdi Beyin Boğaza nazır villası olur. Burası, ziyaret ettiği diğer Türk evleri gibi dışarıya kapalı olmaktan ziyade, daha ferah, dışarıdaki manzaraların, kayıkların kolayca seyredildiği, Avrupai havası olan bir yerdir. Hamdi Beyin Fransız eşi rahatlıkla onlarla birlikte sohbetlere katılabilmekte, yemeklerini birlikte yiyebilmektedir. Kendisi bir Fransız olmasına ve eşinin de uzun süre Avrupa'da bulunmasına rağmen, bu ülkede kadınlar için var olan birçok yasaktan o da kendisini kurtaramamakta ve çoğu zaman eşinin yanında dışarıda bile görünememektedir.

\subsubsection{Osmanlı Kadınlarının Mutsuzluğu}


Başkaca Türk evlerini de ziyaret eden yazar, ev içerisinde ne kadar mutlu gözükmeye çalışırlarsa çalışsınlar, sınırları kesin çizgilerle belirtilmiş, yasaklarla dolu dünyalarında, kadınların mutlu olabileceklerine pek inanmaz. Eserinde yazar, Osmanlı kadınlarının büyük bir sessizlik içerisinde yaşadıkları kapalı mutsuzluklarına duyduğu üzüntüyü, hep dile getirir. Tek düze ve monoton bir hayat yaşayan bu kadınların kurtuluşları ise Avrupa ülkeleriyle olan ilişkilerin daha da gelişmesine bağlıdır. Bu gelişmenin doğal sonucu olarak oralardaki özgürlük havası, bu bölgenin evlerinden dışarıya pek çıkamayan hanımları için ferahlatıcı bir nefes olabilir. Tanzimat'tan Cumhuriyet'e uzanan süreçte ortaya konulan çoğu romanlarımızda; makbul kadın kahramanların Avrupa kültürünü yakından tanıyan, iyi bir yabancı dil bilen özgür kadınlar olduğu bolca karşımıza çıkarak seyahatname yazarının fikirleriyle paralellikler gösterdiği de dikkatlerden uzak değildir (Koçak 2013:728). Avrupa'yla girilen sıkı münasebetler sonucu, erkeklerin kllık kıyafetlerinde ciddi değişiklikler olmuştur. Yazar, zamanla bu yeniliğin, değişikliğin kadınlar üzerinde de görülebileceği umudu içerisindedir. Böylece güzel Türk kadınları, peçenin ve feracenin onları sarıp sarmalayan çirkin görüntülerinden kurtularak güzelliklerinin tadını çıkarabileceklerdir.

Osmanlı paşaları, misafirlerini evlerinde ağırlamak istemeyen insanlardır; çünkü bu davetlere eşleri katılamayacağı için yabancı misafirlerin eşleriyle ilgilenebilecek kimselerin bulunabilmesi gibi bir ihtimal yoktur. Babalarının ve eşlerinin hayatlarını paylaşamayan Türk kadınları, böyle toplantı ve davetlerde görünmez kalmaya hep mahkûm olurlar. Yazara göre Türk kadınları, erkeklerin hayatlarını ne zaman paylaşmaya başlarlarsa ne zaman hiçbir kısıtlamaya muhatap olmadan erkeğiyle birlikte toplum içinde özgürce görünür olmaya başlarlarsa; işte o zaman gerçek mutluluğu yakalamış olacaklardır. Hatta bu zamana kadar da Avrupai tarzda iyi eğitim almalarına ihtiyaç bile yoktur, çünkü bu eğitimleri aracılığıyla öğrenecekleri özgür dünyalar, onlara kendi durumlarını hatırlatan birer mutsuzluk kaynağı olmaktan başka bir işe yarayamayacaktır.

\section{Sonuç}

Kendi dışındaki dünyalara her zaman ilgi duyan Batı düşüncesini en fazla meşgul eden yerlerin başında, yakınındaki Doğu (İslam dünyası) olagelmiştir. Tarihsel süreç içerisinde, karşılarındaki bu rakip dünya, birbirleriyle sımsıkı, iç içe geçmiş hayali veya gerçek imgelerle dokunarak ${ }^{15}$ Batılı zihinleri sürekli uğraştıran bir 'Öteki' olarak kalır. Ötekinin toprakları, İsa'nın çile çektiği kutsal mekânı (Kudüs'ü) da kapsadı̆̆ı için oralara, Batılı ilginin azalması da düşünülemez. Kurtarılması gereken kutsal yerler aşkına başlatılan Haçlı Seferleri, çelişkili görünse de iki toplumun birbirlerini daha yakından tanımalarına güçlü bir etkileşim ağı oluşturmalarına- zeminler hazırlar, köprüler oluşturur. Çeşitli boyutlar kazanarak yoluna devam eden bu iki dünyanın sorunlu yan yanalığı, tarihsel süreç içerisinde, sürekli Batı lehine gelişir.

Başlattığı keşifler sayesinde güçlenen Batı, karşılarındaki Osmanlı İmparatorluğunun zamanla bir durağanlığa girdiğini kavramada gecikmez. Kendini güçlü görmenin verdiği rahatlık ve güven ortamı içerisinde, artık dünyaya farklı gözle bakan bir Batı için Öteki kabul ettikleri dünyanın diğer tarafları; fethedilecek, boyun eğdirilecek, sömürgeleştirilecek, keşfedilip, zenginlikleri ele geçirilecek yerlerden öte bir anlam ifade etmemeye başlar. Bu amaçla yavaş yavaş Osmanlı’nın geniş topraklarına yerleşmenin

\footnotetext{
15 “Halk yığınlarının gerçek Doğu’ya, politik Doğu’ya onun tarihine ve farklılıklarına olan ilgisi sıfırdır ya da hemen hemen hiçtir. Buna karşlık, Haçlı seferleri ve onlarla birlikte taşınan masal-efsane karışımı söylentiler, bir düşünce sistemi olarak, karşı tarafın ideolojisi hakkında, genel, yapay, kendisini eğlendiren ve tatmin eden bir imaja susamış geniş halk yı̆̆ınları yaratı.” (bkz. Thierry Hentsch, Hayali Doğu, Batı'nın Akdenizli Doğu’ya Politik Bakışı, Metis, 2008, s. 68.)
} 
de zamanının geldiğine inanılır. Uzun zamandır Doğu'da bulunan seyyahların, casusların, elçilerin, konsolosların, tüccarların yanında bilginlerin de yerlerini aldığını görürüz.

On yedinci ve on sekizinci yüzyıllar, artan merak sayesinde, Yakındoğu’ya seyahatlerin yoğunlaştı̆̆ı bir dönemdir. Güçlü Batı'nın farklı bir gözle baktığı Osmanlı İmparatorluğu, seyyahlar aracılığıyla bütün yönleriyle tanınmaya çalışılır. Sayısı hayli artmış bir şekilde, Doğu topraklarına yayılan Batı'nın meraklı gezginleri, buralarda buldukları bilgi birikimlerini vatanlarına taşıyacaklar; adeta Doğu'nun hafızasına, beynine sahip olacaklardır. Bunlarla da yetinmeyerek, gemiler dolusu tarihsel değerler (heykeller, kabartmalar, dikili taşlar) yerlerinden edilecek ve arkasından elde ettikleri büyük bilgi birikimlerinin ışığı altında, ameliyat masasına yatırılması kaçınılmaz olacaktır, geniş bir coğrafyayı kaplamasına rağmen Doğu'nun gücünü kaybetmeye başlamış bu İmparatorluğunun.

On dokuzunu asırla birlikte gücünün zirvesine ulaşan Batı, kendi dışındaki dünyaların güçsüzlüğünün de oldukça farkındadır. Elde ettiği geniş bilgi yığının verdiği özgüvenle ve emperyalist iştahı da epeyce artmış olarak, egzotik duygular içerisinde yaklaştığı Osmanlı devletine, öldürücü son darbeyi ne zaman vuracağının tereddüdü içerisindedir. Siyasetçiler, Avrupa’nın Hasta Adamının topraklarını ele geçirmeyi düşünürlerken; seyyahlar, ressamlar, romancılar, şairler de boş durmayarak Doğu'ya ait romantik bir egzotizmle, Batı muhayyilesine ilham verme gayreti içerisine girerler.

İşte böyle bir ortamda Osmanlının payitahtına eşiyle gelen G. A. Müller, diğer birçok seyyahın aksine, daha nesnel bir gözle yansıtmaya çalışır -artık son demlerini yaşayan Şark’ın büyük İmparatorluğundaşahit olduklarını. Diğer çoğu seyyahlar gibi onu da en fazla etkileyen şey İstanbul'un uzaktan görüntüsü olur. İstanbul, tepeleriyle, ışıklı minareleriyle, kubbeleriyle, güneşli gündüzüyle ve özellikle de mehtaplı geceleriyle ziyaretçileri için bir görsel şölen sunan mabet gibidir. Fakat ona doğru yaklaştıkça bu güzelliğin hepsi kaybolarak kirli sokaklarıyla, pis kokusuyla, harabe evleriyle, her yönden kendini belli eden fakirliğiyle ve hiç dinmeyen köpek sesleriyle yorgun imparatorluğun yıldızları birer birer sönmekte olan şehriyle yüz yüze kalırlar, uzaktan gelen ziyaretçiler.

Kadın olmanın ona sağladığı kolaylığı iyi değerlendiren Leydi Müller, erkek seyyahların görebilmeleri imkansız olan Osmanlı haremi hakkında mektuplarında geniş bilgilere yer verir. Önyargısız bir sevgiyle yaklaştığı Osmanlı kadını, kendi küçük dünyalarında mutlu gibi gözükmektedir. Yalnız evlerinin, bahçelerinin duvarları arkasında yaşamaya -erkekler tarafından- mecbur bırakılan bu güzel kadınların gerçek mutluluğa ulaşabilmeleri, Avrupalı hemcinsleri gibi iyi bir eğitim alarak toplum içerisine özgürce çlkabildikleri zaman ancak gerçekleşmiş olacaktır.

\section{Kaynakça}

Almond, Ian (2015). Yeni Oryantalistler, Nietzsche'den Orhan Pamuk'a İslam'n Postmodern Temsilleri, çev: Bahar Çetiner -Talha Can İşsevenler, İstanbul, Pinhan Yayıncılık.

Barkeretal, Francis (1984). Europe and Its Others, The University of Essex.

Behdad, Ali (2007). Kolonyal Çözülme Çağında Oryantalizm, çev: Sibel Erduman - Berkay Ersöz, İstanbul, Chiviyazıları Yayınevi.

Beyhan, Mehmet Ali (2013). Geçmişten Günümüze Seyahatler ve Seyahatnameler, İstanbul, Kitabevi Yayınları.

Bulut, Yücel (2010). Oryantalizmin Kısa Tarihi, İstanbul, Küre Yayınları.

Carrington, Dorothy (1947). The Traveller's Eye, London. 
Çelik, Zeynep (1986). The Remaking of İstanbul: Portrait of an Ottoman City in the Nineteenth Century, London.

Daniel, Norman (1980). Islam and the West: the Making of an Image, Edinburgh.

Davison, Roderick H. (1963). Reform in The Ottoman Empire, 1856-1876, Princeton.

Derin, Süleyman (2006). İngiliz Oryantalizmi ve Tasavvuf, İstanbul, Küre Yayınları.

Dwight, Henry, O. (1901). Constantinople and its Problems, London.

Eliot, Sir Charles (1900). Turkey in Europe, London.

Ellison, Grace (2009). İstanbul'da Bir Konak ve Yeni Kadınlar, İngiliz Kadın Gazetecinin Gözüyle Türk Evi ve Gündelik Hayat, çev: Neşe Akın, İstanbul, Dergâh Yayınları.

Eravcı, H. Mustafa (2010). Avrupa'da Türk İmajı, Konya, Çizgi Kitabevi.

Fanon, Frantz (2013). Yeryüzünün Lanetlileri, çev: Şen Süer, İstanbul, Versus Kitap.

Fanon, Frantz (1965). A Dying Colonialism, çev: Haakon Chevalier, New York.

Fusseli, Paul(1980). Abroad: British Literary Travelling Between The Wars, Oxford.

Germaner, Semra - Zeynep İnankur(1989) Orientalism and Turkey, İstanbul.

Gökçe, Gülise - Orhan(2011) Avrupa'da İslam ve Türk İmajı, Ankara, Birleşik Kitabevi.

Hamlin, Cyrus (1878). Among the Turks, New York.

Hamlin, Cyrus (1893). My Life and Times, Boston.

Harvey, Annie Jane (1871). Turkish Harems and Circassian Homes, London.

Hentsch, Thierry (2007). Hayali Doğu, Batı’nın Akdenizli Doğu’ya Politik Bakışı, çev: Aysel Bora, İstanbul, Metis Yayıncilık.

Hourani, Albert (1993). Islam in European Thought, Cambridge.

Hussain, Asaf (1984). Orientalism, Islam and Islamist, The Ideology of Orientalism, USA.

Irwin, Robert (2008). Oryantalistler ve Düşmanları, çev: Bahar Tırnakçı, İstanbul, Yapı Kredi Yayınları.

Kabbani, Rana (1986). Europe's Myths of Orient: Devise and Rule, Basingstoke.

Kahf, Mohja (2006). Batı Edebiyatında Müslüman Kadın İmajı, çev: Yeşim Sezdirmez, İstanbul, Küre Yayınları.

Kiernan, V. G. (1969). The Lord of Humankınd, Black Man, Yellow Man and White Man in an Age of Empire, Boston.

Koçak. Ahmet (2013). Türk Romanında Avrupa (1872-19oo), İstanbul

Kula, Onur Bilge (2012). Batı Felsefesinde Oryantalizm ve Türk İmgesi, İstanbul, Türkiye İş Bankası Yayınları.

Kula, Onur Bilge (2011). Batı Edebiyatı’nda Oryantalizm I-II, İstanbul, Türkiye İş Bankası Yayınları.

Lewis, Raphaela (1971). Everyday Life in Ottoman Turkey, London.

Lewis, Reina (1996). Genderin Orientalism: Race, Feminity and Representation, London.

Lowe, Lisa (1991). Critical Terrains: French and British Orientalism, London.

Löschburg, Winfried(1998). Seyahatin Kültür Tarihi, çev: Jasmin Traub, Ankara, Dost Kitabevi.

Macfarlane, Charles (1829). Constantinople in 1828: a Residence of Sixteen Months in the Turkish Capital and Provinces with an Account of the Present State of the Naval and Military Power and of the Resources of the Ottoman Empire, London. 
Macfarlane, Charles (1850). Turkey and its Destiny: The Results of Journeys Made in 1847 and 1848 to Examine into the State of that Country, London.

Mansel, Philip (1995). Constantinople City of the World's Desire 1453-1924, London.

Melman, Billie (1992). Women's Orients: English Women and the Middle East, Basingstoke.

Meriç, Ümit (2010). Seyyahların Aynasında Şehirlerin Sultanı İstanbul, İstanbul, Albaraka Türk Yayınları.

Mills, Sara (1991). Discourses of Difference: An Analysis of Women's Travel Writing and Colonialism, London.

Montagu, Lady Mary Wortley (1965). The Complete Letter of Lady Mary Wortley Montagu Vol. I, 17o81720, ed: Robert Halsband, Oxford.

Muller, Mrs. Max(1897). Letters from Constantinople, London.

Murray, John (1893). Handbook for Travellers in Turkey, London.

Neave, Dorina L. (2008). Sultan Abdülhamit Devrinde İstanbul'da Gördüklerim, çev: Neşe Akın, İstanbul, Dergâh Yayınları.

de Nerval, Gerard (1974). Muhteşem İstanbul, çev: Refik Özbek, İstanbul.

Ortayl, İlber (2005). İmparatorluğun En Uzun Yüzyıll, İstanbul, Alkım Yayınları.

Pardoe, Julia (1837). The City of the Sultans and Domestic Manner of the Turks in 1836, London.

Pardoe, Julia (1838). The Beauties of the Bosphorus, London.

Parla, Jale (2012). Efendilik, Şarkiyatçılık, Kölelik, İstanbul, İletişim Yayınları.

Porter, Dennis (1991). Haunted Journeys, Desir and Transgression in Auropean Travel Writing, Princeton University Press.

Rodinson, Maxime (2003). İslam’nn Mirası, Batı’yı Büyüleyen İslam, çev: Cemil Meriç, İstanbul, Pınar Yayınları.

Said, Edward W. (1995). Orientalism, Western Conceptions of the Orient, Penguin.

Said, Edward W. (1983). The World, The Text, and the Critic, Cambridge.

Said, Edward W. (1993). Culture and Imperialism, London.

Sharafuddin, Mohammed (1994). Islam and Romantic Orientalism, London.

Şahin, Gürsoy (2007). İngiliz Seyahatnamelerinde Osmanl Toplumu ve Türk İmajı, İstanbul, Gökkubbe Yayınları.

Thompson, Carl (2011). Travel Writing, London,

Üçel-Aybet, Gülgün (2003). Avrupalı Seyyahlarn Gözünden Osmanl Dünyası ve İnsanları （15301699), İletişim Yayınları, İstanbul.

Wheatcroft, Andrew (1995). The Ottomans, Dissolving Images, London, Penguin.

Yeğenoğlu, Meyda (2003). Sömürgeci Fantaziler, Oryantalis Söylemde Kültürel ve Cinsel Fark, İstanbul, Metis Yayıncllk.

Young, Robert (1990). White Mythologies: Writing History and the West, London.

Young, Robert (1995). Colonial Desire: Hybridity in Theory, Culture and Race, London.

Young, Robert (2002). Postcolonialism: A Historical Introduction, London. 